\title{
STRUCTURAL BEHAVIOUR OF REINFORCED CONCRETE BEAMS CONTAINING A NOVEL LIGHTWEIGHT AGGREGATE
}

\begin{abstract}
This paper reports the results of an experimental investigation into the structural behaviour of reinforced concrete beams incorporating a novel EPS-based Lightweight Aggregate (LWA) called Stabilised Polystyrene (SPS) aggregate. Four concrete mixtures with Water to Cement ratio (W/C) of 0.8 were used. The replacement levels of natural aggregate by SPS were 0, 30, 60 and 100\%. The volume ratio to manufacture SPS aggregate was 8:1:1 (80\% waste EPS: $10 \%$ cement: $10 \%$ clay). A total of 24 beams were cast and tested at 28-day age. Three types of tension reinforcement were used: 2 bars, 3 bars and 2 bars + shear links. There were no compression bars at the top for all beams. Four pointloading flexural tests were conducted up to failure. In general, it can be observed that the structural behaviour of SPS concrete beams is similar to that of other types of lightweight aggregate concretes used around the world.
\end{abstract}

Keywords: Waste Polystyrene; Lightweight Aggregates; Compressive Strength; Structural Behaviour; Deflection; Reinforced Concrete Beam.

\section{Introduction}

Expanded Polystyrene (EPS) is a thermoplastic material and is mainly used as packaging and insulating products in various industrial fields around the world. A large quantity of EPS is disposed of as waste and left as stockpiles, landfill material or illegally dumped in selected areas. It has been reported that more than 112,000 tons of EPS were used for post-consumer protective packaging in the USA only in 1996. It has also been reported that around 300,000 tons of waste EPS are disposed of in landfill in the UK each year; because up to $95 \%$ of EPS is air, it occupies $38,000,000 \mathrm{~m}^{3}$ of space in landfill, which is enough to fill 15,000 Olympicsized swimming pools! This will ultimately cause pollution and is harmful to the ecosystem. National and international environmental regulations have also become more inflexible, causing this waste to become increasingly expensive to dispose. Therefore, utilising waste 
polystyrene in place of natural aggregate in lightweight aggregate concrete production not only solves the problem of disposing this ultra-light solid waste but also helps preserve natural resources [1, 2, 3]. However, EPS beads are extremely light with very low densities which can cause segregation in mixtures. In addition, EPS beads are hydrophobic, which results in poor bonding to cement paste. Hence, some researchers $[4,5,6,7,8,9,10]$ have conducted experiments to improve the properties and resistance to segregation including adding some bonding additives such as aqueous epoxy emulsions and aqueous dispersions of polyvinyl propionate, chemically pre-treated EPS beads, adding ultra-fine SF to improve the bonding between EPS and cement paste, using super-plasticisers to increase the workability of concrete, and thermal modification etc. However, these techniques may not be sustainable, environmentally friendly and readily available around the world. The novel technique used in the present study to produce a novel lightweight aggregate (LWA) will improve the resistance to segregation of EPS beads, increase the utilisation of waste materials and contributes towards sustainable development.

\section{Previous Work}

The bond performance of reinforced EPS concrete using glass fibre reinforced polymer (GFRP) bars was examined earlier [11]. They used three surface treatment methods for the bars: 1) Smooth and circular GFRP bar; 2) Smooth and elliptical GFRP bar; 3) Sand-coated circular GFRP bar). They observed that the type 3 bar (sand-coated circular bar) obtained the highest bond strength. The bond strength increased with an increase in the compressive strength and density of EPS concrete.

Researchers [12] investigated the flexural behaviour of reinforced lightweight aggregate concrete beams containing oil palm shell. The beams with varying reinforcement ratios were tested and their strength, cracking, deformation and ductility behaviour were examined. The investigation revealed that the flexural behaviour of reinforced concrete beams made from oil palm shell aggregate was comparable to that of other lightweight concretes and the experimental results satisfied the serviceability requirements of the Codes of Practice.

Researchers [13] investigated the characterisations of structural behaviour of reinforced lightweight aggregate concrete beams made with polystyrene aggregate strengthened with near surface mounted (NSM) glass fibre reinforced polymer (GFRP) bars. The parameters examined in their investigation were type of concretes (Control and polystyrene concretes), type of reinforcing bars (GFRP and steel), and type of adhesives. The modes of failure, 
moment-deflection response and ultimate moment capacity of the beams were examined. The results showed that beams with NSM GFRP bars showed a reduction in ultimate deflection and an improvement in flexural stiffness and bending capacity, depending on the polystyrene aggregate content. In general, beams strengthened with NSM GFRP bars overall showed a significant increase in ultimate moment ranging from $23 \%$ to $53 \%$ over the corresponding beams without NSM GFRP bars. The influence of epoxy (adhesive) type was found conspicuously dominated the moment-deflection response up to the peak moment.

Others [14] studied engineering properties of EPS aggregate concrete by partially replacing natural coarse aggregate with equal volume of the chemically coated polystyrene at the levels of 30, 50 and 70\%. They found that compressive strength, unit weight and modulus of elasticity decreased and drying shrinkage and creep increased with increasing EPS aggregate replacement in concrete.

According to the literature, the primary use of concrete containing Expanded Polystyrene (EPS) has been in the manufacture of non-structural components for buildings (e.g. roof insulation, partition walls etc.). However, the structural use of this concrete has been prevented due to the lack of knowledge on its structural properties. This paper presents the results of an experimental investigation into the structural behaviour of reinforced concrete beams incorporating an EPS-based Lightweight Aggregate (LWA) called Stabilised Polystyrene (SPS) aggregate using a novel technique.

\section{Experimental Programme}

\subsection{Materials}

The cement used was Portland cement. The chemical (composition) characteristics of cement are given in Table 1. The natural aggregate used was a low cost aggregate with bulk density of $1673 \mathrm{~kg} / \mathrm{m}^{3}$, water absorption of $1.1 \%$, specific gravity of 2.65 , Saturated Surface Dry (SSD) specific gravity of 2.67 and $0-8 \mathrm{~mm}$ in sizes conforming to the British standard requirements. The particle size distributions (sieving) details of natural aggregate according to BS EN 933-1 [15] are presented in Fig. 1. The properties of natural aggregate are presented in Table 2. A novel waste EPS-based aggregate called Stabilised Polystyrene (SPS) was also used to replace natural aggregate partially and totally in the concrete mixtures. 
Table 1: Chemical compositions of the cement

\begin{tabular}{|l|l|l|l|l|l|l|l|l|l|l|}
\hline Constituent & $\mathrm{SiO}_{2}$ & $\mathrm{Al}_{2} \mathrm{O}_{3}$ & $\mathrm{Fe}_{2} \mathrm{O}_{3}$ & $\mathrm{CaO}$ & $\mathrm{MgO}$ & $\mathrm{SO}_{3}$ & $\mathrm{~K}_{2} \mathrm{O}$ & $\mathrm{Na}_{2} \mathrm{O}$ & $\mathrm{Cl}$ & LOI \\
\hline Value (\%) & 22.8 & 3.8 & 1.4 & 66.5 & 0.8 & 3.3 & 0.7 & 0.1 & $<0.1$ & 1.5 \\
\hline
\end{tabular}

\subsubsection{Manufacturing Process of SPS Aggregate}

The general description of manufacturing process of this novel lightweight aggregate is shown in Fig. 2. In the present study, and in order to improve the resistance to segregation of EPS particles, a new technique has been used. The crushed waste polystyrene, clay and cement were mixed with water then formed into "cake" which was then dried (cured in the controlled laboratory environment of $20 \pm 2^{\circ} \mathrm{C}$ and $60-70 \%$ Relative Humidity (RH) for 14 days) and re-crushed into a novel LWA called SPS. A volume ratio of 8:1:1:1.5 (80\% waste EPS: $10 \%$ clay powder: $10 \%$ Portland cement: water) was adopted. Although no detailed study was conducted on the effect of bond between binder (coating) and EPS; it was found that the proportion; $80 \%$ (EPS)-10\%(cement)-10\%(clay) has given the best proportions in terms of working with the materials and increasing the utilisation of waste EPS (i.e. the best thickness of the coating that densifies the materials and enhances the bond between EPS particles and mortar without using too much cement). The water to cement + clay ratio $(\mathrm{W} /(\mathrm{C}+\mathrm{C}))$ was 0.75 . The enhanced cohesiveness of the binder at the time of wet mixing avoided the problem of very light particles separating and floating to the top of the mix. The particle size distributions (sieving) details of SPS aggregate according to BS EN 933-1 [15] are presented in Fig. 1. The properties of SPS aggregate are presented in Table 2.

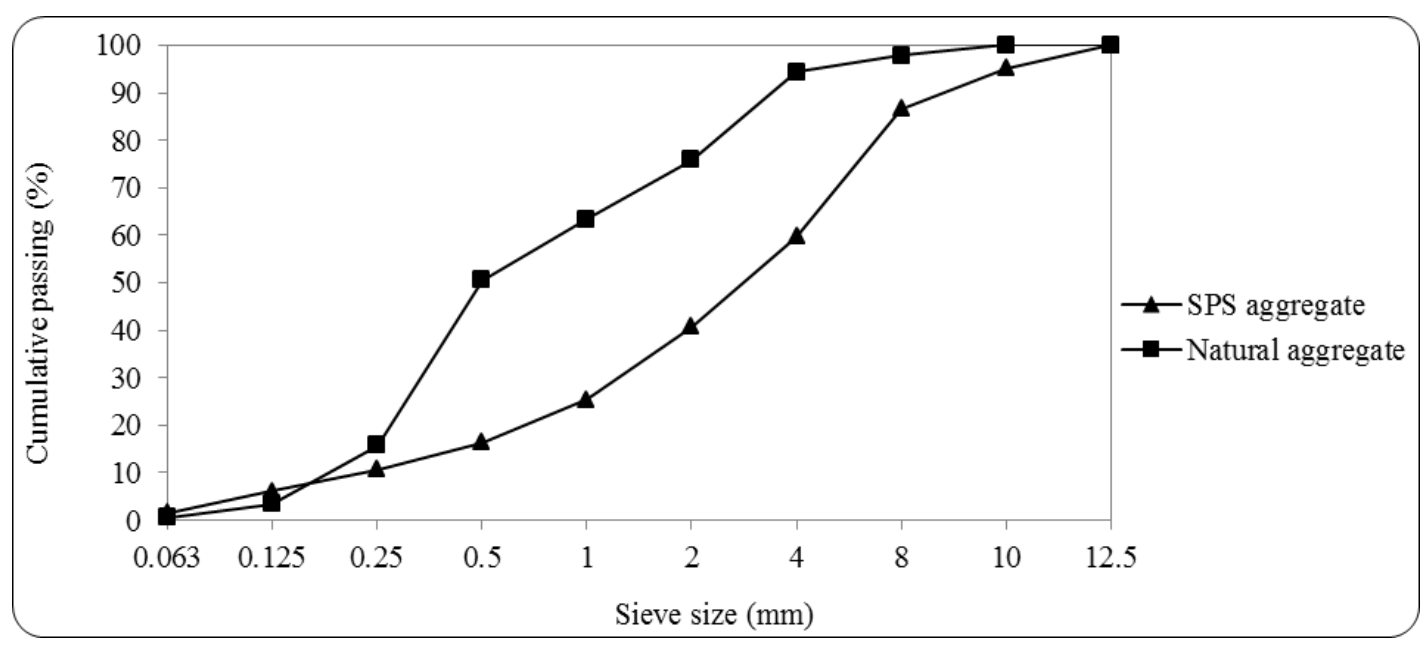

Fig. 1: Particle size distributions of natural and SPS aggregates 


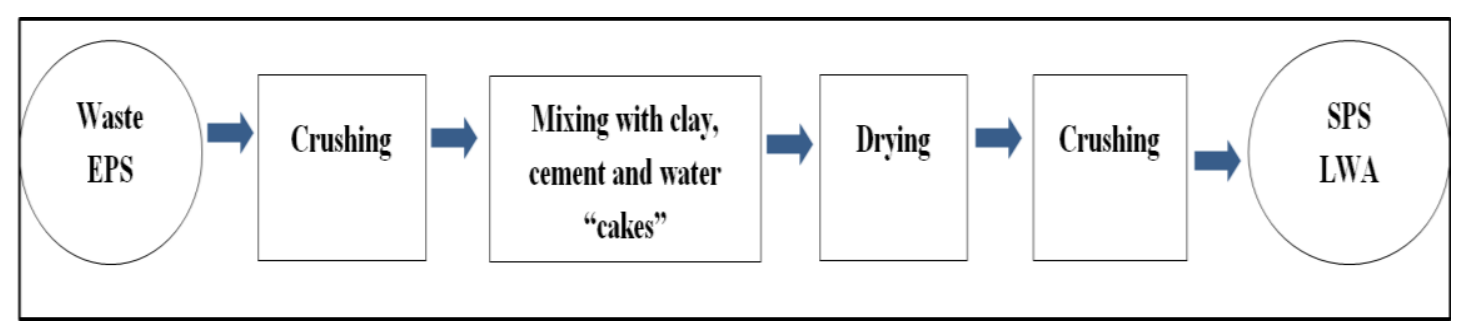

Fig. 2: Manufacturing process of SPS LWA

Table 2: Properties of natural and SPS aggregates

\begin{tabular}{lcc}
\hline \multicolumn{1}{c}{ Properties } & SPS aggregate & Natural aggregate \\
\hline Bulk density $\left(\mathrm{Kg} / \mathrm{m}^{3}\right)$ & 457 & 1673 \\
Specific gravity $(\mathrm{SSD})$ & 0.80 & 2.67 \\
Water absorption $24 \mathrm{~h}(\%)$ & 13.0 & 1.1 \\
\hline
\end{tabular}

For this experimental programme, four concrete mixtures with three different reinforcement types were carried out consisting of twenty-four reinforced concrete beams with rectangular cross-sections of $100 \mathrm{~mm}$ width $\times 150 \mathrm{~mm}$ depth $\times 700 \mathrm{~mm}$ length. The cement content and the W/C ratio were kept constant at $320 \mathrm{~kg} / \mathrm{m}^{3}$ and 0.8 , respectively. The control mixture had a proportion of 1 (cement): 6 (natural aggregate).

Each mix comprised six beams; the first two beams containing 2 tension reinforcement steel bars only without shear reinforcement (without stirrups) (Type 1), two beams containing 3 tension reinforcement steel bars only without shear reinforcement (without stirrups) (Type 2) and the last two beams containing 2 tension reinforcement steel bars with shear reinforcement (with stirrups) (Type 3). Compression reinforcement was not used for any of the concrete beams. The first mixture, which is the control mixture, comprised natural aggregates and the remaining mixes were partially and fully replaced with an increasing amount of SPS aggregates by volume. The percentage replacements were $0,30,60$, and 100\%. Table 3 illustrates the details of concrete mixtures. The reinforcement details of concrete beams are presented in Table 4.

Experimental work comprised of structural tests was conducted on three types of reinforcement for concrete beams containing varying amounts of SPS aggregate. The beams are simply supported and tested under two-point loading (Fig. 3). The beams were loaded in $2 \mathrm{kN}$ increments until failure and the following structural observations were made:

- Load-deflection behaviour at mid-span for each increment;

- Mode of failure, crack pattern and load at first crack; 
- Strain distribution at mid-span for load increment and the corresponding change in the neutral axis position.

For each mixture six cubes were cast and tested just after each beam was tested to determine the concrete's compressive strength.

Table 3: Details of mixtures

\begin{tabular}{|c|c|c|c|c|c|c|}
\hline \multirow{2}{*}{ Series No. } & \multirow{2}{*}{$\mathrm{W} / \mathrm{C}$} & \multirow{2}{*}{ Mix No. } & \multirow{2}{*}{ SPS $(\%)$} & \multicolumn{3}{|c|}{ Mixture Constituents $\left(\mathrm{kg} / \mathrm{m}^{3}\right)$} \\
\hline & & & & Cement & Water & $\mathrm{NA}\left(\mathrm{kg} / \mathrm{m}^{3}\right)+\mathrm{SPS}(\%)$ \\
\hline \multirow{4}{*}{1} & \multirow{4}{*}{0.8} & 1 & 0 & 320 & 256 & $1920+0$ \\
\hline & & 2 & 30 & 320 & 256 & $1344+30$ \\
\hline & & 3 & 60 & 320 & 256 & $768+60$ \\
\hline & & 4 & 100 & 320 & 256 & $0+100$ \\
\hline
\end{tabular}

SPS - stabilised polystyrene, ( $\%$ by volume); NA - natural aggregate

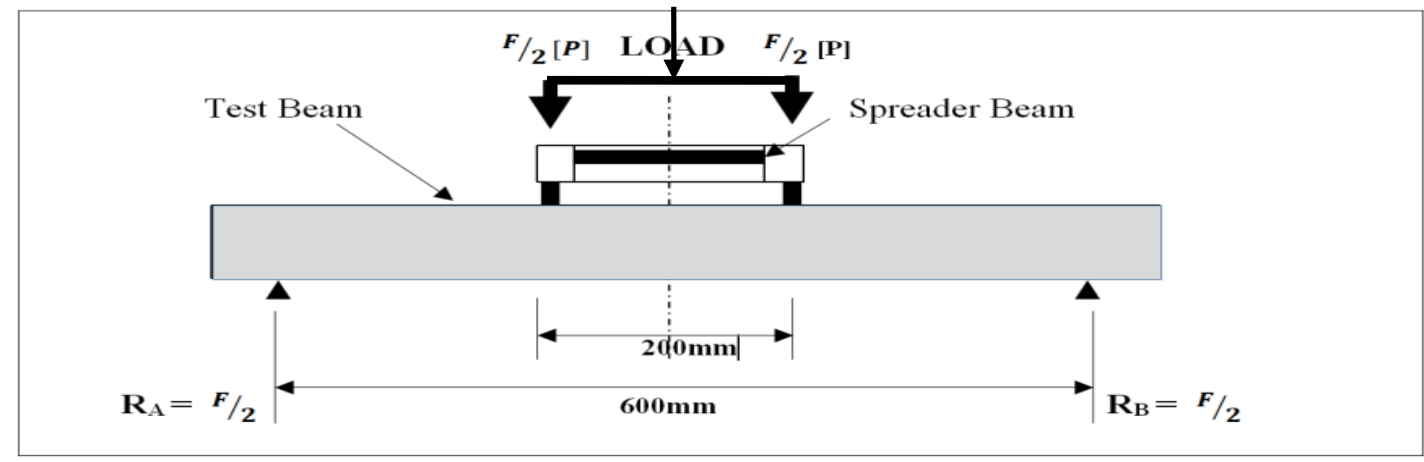

Fig. 3: Loading set-up for the reinforced concrete beam specimens

Table 4: Reinforcement details of beams

\begin{tabular}{|c|c|c|c|c|c|c|c|c|c|}
\hline $\begin{array}{l}\text { Beam } \\
\text { Code }\end{array}$ & $\begin{array}{l}\text { Tension } \\
\text { Reinf. } \\
\text { No. and } \\
\text { Size } \\
\end{array}$ & $\begin{array}{c}\text { Compres. } \\
\text { Reinf. } \\
\text { No. and } \\
\text { Size }\end{array}$ & $\begin{array}{l}\text { Shear } \\
\text { Links } \\
\text { No. }\end{array}$ & $\begin{array}{c}\text { Beam Size } \\
\text { B×D } \\
(\mathrm{mm})\end{array}$ & $\begin{array}{c}\text { Area of } \\
\text { Tensile } \\
\text { Steel, As } \\
\left(\mathrm{mm}^{2}\right)\end{array}$ & $\begin{array}{l}\mathrm{As} / \\
\mathrm{b} \times \mathrm{d} \\
(\%)\end{array}$ & $\begin{array}{c}\text { Tensile } \\
\text { Steel } \\
\text { Weight } \\
(\mathrm{g})\end{array}$ & $\begin{array}{c}\text { Shear } \\
\text { Links } \\
\text { Weight } \\
(\mathrm{g})\end{array}$ & $\begin{array}{c}\text { Total } \\
\text { Steel } \\
\text { Weight } \\
\text { used }(\mathrm{g}) \\
\end{array}$ \\
\hline M5-1A & $2 \varnothing 8$ & 0 & 0 & $150 \times 100$ & 100 & 0.8 & 535.2 & 0 & 535.2 \\
\hline M5-1B & $2 ø 8$ & 0 & 0 & $150 \times 100$ & 100 & 0.8 & 535.2 & 0 & 535.2 \\
\hline M5-2A & $3 \not 8$ & 0 & 0 & $150 \times 100$ & 151 & 1.2 & 802.8 & 0 & 802.8 \\
\hline M5-2B & $3 \varnothing 8$ & 0 & 0 & $150 \times 100$ & 151 & 1.2 & 802.8 & 0 & 802.8 \\
\hline M5-3A & $2 \varnothing 8$ & 0 & 10 & $150 \times 100$ & 100 & 0.8 & 535.2 & 1817.0 & 2352.2 \\
\hline M5-3B & $2 ø 8$ & 0 & 10 & $150 \times 100$ & 100 & 0.8 & 535.2 & 1817.0 & 2352.2 \\
\hline
\end{tabular}




\begin{tabular}{|c|c|c|c|c|c|c|c|c|c|}
\hline M6-1A & $2 \not 8$ & 0 & 0 & $150 \times 100$ & 100 & 0.8 & 535.2 & 0 & 535.2 \\
\hline M6-1B & $2 \not 88$ & 0 & 0 & $150 \times 100$ & 100 & 0.8 & 535.2 & 0 & 535.2 \\
\hline M6-2A & $3 \not 8$ & 0 & 0 & $150 \times 100$ & 151 & 1.2 & 802.8 & 0 & 802.8 \\
\hline M6-2B & $3 ø 8$ & 0 & 0 & $150 \times 100$ & 151 & 1.2 & 802.8 & 0 & 802.8 \\
\hline M6-3A & $2 \not \varnothing 8$ & 0 & 10 & $150 \times 100$ & 100 & 0.8 & 535.2 & 1817.0 & 2352.2 \\
\hline M6-3B & $2 \not 8$ & 0 & 10 & $150 \times 100$ & 100 & 0.8 & 535.2 & 1817.0 & 2352.2 \\
\hline M7-1A & $2 \not 88$ & 0 & 0 & $150 \times 100$ & 100 & 0.8 & 535.2 & 0 & 535.2 \\
\hline M7-1B & $2 \not 8$ & 0 & 0 & $150 \times 100$ & 100 & 0.8 & 535.2 & 0 & 535.2 \\
\hline M7-2A & $3 ø 8$ & 0 & 0 & $150 \times 100$ & 151 & 1.2 & 802.8 & 0 & 802.8 \\
\hline M7-2B & $3 \varnothing 8$ & 0 & 0 & $150 \times 100$ & 151 & 1.2 & 802.8 & 0 & 802.8 \\
\hline M7-3A & $2 ø 8$ & 0 & 10 & $150 \times 100$ & 100 & 0.8 & 535.2 & 1817.0 & 2352.2 \\
\hline M7-3B & $2 \not 8$ & 0 & 10 & $150 \times 100$ & 100 & 0.8 & 535.2 & 1817.0 & 2352.2 \\
\hline M8-1A & $2 ø 8$ & 0 & 0 & $150 \times 100$ & 100 & 0.8 & 535.2 & 0 & 535.2 \\
\hline M8-1B & $2 \not 8$ & 0 & 0 & $150 \times 100$ & 100 & 0.8 & 535.2 & 0 & 535.2 \\
\hline M8-2A & $3 \varnothing 8$ & 0 & 0 & $150 \times 100$ & 151 & 1.2 & 802.8 & 0 & 802.8 \\
\hline M8-2B & $3 ø 8$ & 0 & 0 & $150 \times 100$ & 151 & 1.2 & 802.8 & 0 & 802.8 \\
\hline M8-3A & $2 \not \varnothing 8$ & 0 & 10 & $150 \times 100$ & 100 & 0.8 & 535.2 & 1817.0 & 2352.2 \\
\hline M8-3B & $2 \varnothing 8$ & 0 & 10 & $150 \times 100$ & 100 & 0.8 & 535.2 & 1817.0 & 2352.2 \\
\hline
\end{tabular}

\subsection{Beam Specifications}

A total of 24 reinforced concrete beams were cast from four different mixtures as stated previously (Table 4). There were no compression bars at the top for all beams, but those in tension consisted of two and three for each mix combination. The variation in the number of bars on the tension side was used to obtain more data which could be used to maximise the efficiency/performance of reinforced concrete beams for low-cost housing and reduce the overall dead load of construction. The tension bars were $8 \mathrm{~mm}$ diameters. The shear links (stirrups) were also $8 \mathrm{~mm}$ diameters and were used for Type 3 beams only. In Type 3 beams, there were no shear links (stirrups) between two loading points $(200 \mathrm{~mm})$ but they were instead placed at $50 \mathrm{~mm}$ from the sides towards the loading points (between supports and loading points). The reinforcement arrangement for Types 1, 2, and 3 is shown in Figs. 4, 5 
and 6, respectively. The steel reinforcement bars were already cut to size by the manufacturer. The steel stirrups were also bent to the appropriate dimensions; consequently for the Type 3 reinforcement cage, the reinforcement and steel stirrups were then assembled using traditional wires.

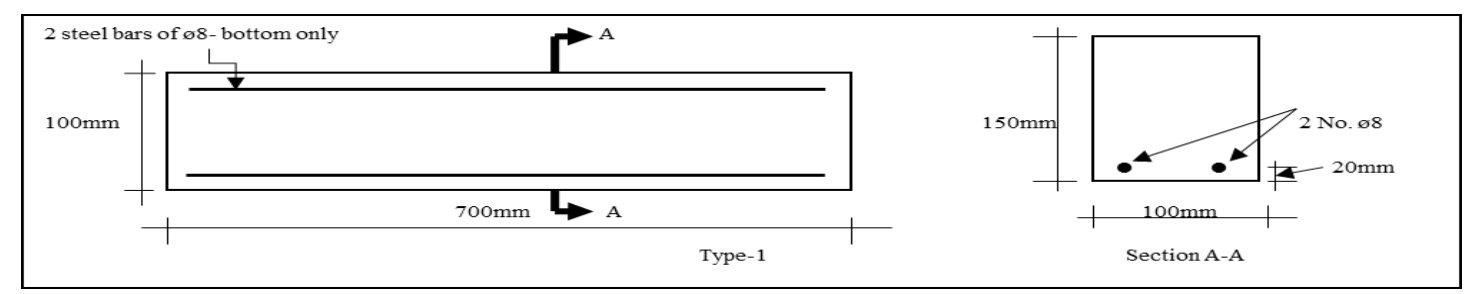

Fig. 4: Reinforcement details and layout for beams containing $2 \mathrm{~T} 8$ at tension side (Type 1)

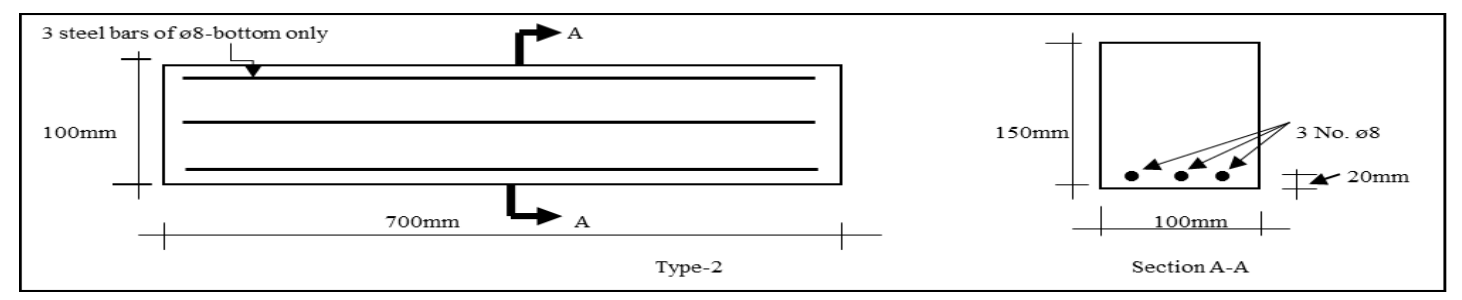

Fig. 5: Reinforcement details and layout for beams containing 3T8 bars at tension side (Type 2)

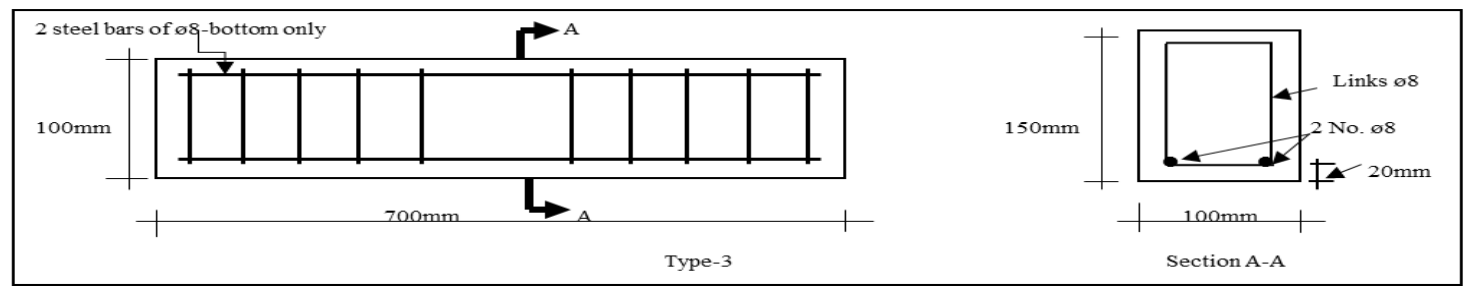

Fig. 6: Reinforcement details and layout for beams containing $2 \mathrm{~T} 8$ at tension side with shear links (Type 3)

\subsection{Mixing, Casting and Curing of Beams}

A plywood mould was used for the casting of beams whereas steel moulds conforming to BS EN 12390-1 [16] were used for the cubes. Before casting began, the moulds were visually inspected and cleaned thoroughly. Thereafter, a thin layer of oil was applied to the inside surfaces of the moulds for easy de-moulding.

The concrete mixer was then cleaned and slightly damped with a wet cloth to avoid any absorption of water by the concrete mixer. The natural aggregate, cement and SPS aggregates were then gently poured into the mixer according to their required quantities. Once all the dry materials were inside the mixer, water was then poured in little by little (1/3) while mixing. After 3-5 minutes of thorough mixing until the required texture of the concrete was obtained, the mixing process was stopped and a slump test was carried out in accordance with BS EN 
12350-2:2009 [17] to test the fresh concrete properties such as concrete consistency and the workability.

In the meantime the pre-prepared reinforcement was gently placed into the moulds and appropriate cover $(20 \mathrm{~mm})$ was provided for top and bottom along with both sides. Using a shovel, concrete was poured in two layers; each layer was compacted using a vibrating table. The vibrating table was used instead of the poker vibrator due to the lightweight nature of the polystyrene material. Subsequently, using a trowel the top surface was levelled and neatly trimmed as best as possible.

Along with the beams, six cubes of $100 \mathrm{~mm}$ from each mix combination were also prepared to determine the compressive strength comply with BS EN 12390-3:2009 [18] of concrete; concrete was poured into the steel moulds in three equal layers, then compacted using the vibrating table to a smooth finish and top surface. The completed beams and cubes were then left to settle down for approximately 24 hours at room temperature. The following day they were de-moulded and marked with the corresponding mixture propositions. The beams and cubes were wrapped with plastic sheets then cured at room temperature (at about $\left.20^{\circ} \mathrm{C}\right)$. They were in the curing process for 28 days.

\section{Results and Discussions}

\subsection{Workability and Density}

The slump values for concretes containing varying amounts of SPS aggregate are presented in Fig. 7. The slump values were in the range of 3-36mm. Without the use of superplasticiser and with other factors (including W/C ratio and cement content) kept constant, the workability of the concrete increased with the increase in SPS content up to $60 \%$ before starting to decrease. At $100 \%$ SPS the slump was lower than that of $60 \%$ SPS (Fig. 7). The decrease in concrete workability with higher percentages of SPS aggregate (100\% SPS) may be due to increasing surface area or the absorption of a significant amount of water and cement paste by SPS aggregate. However, the pre-wetted method of SPS aggregate (wetted with the compensated aggregate absorption) mitigated this loss of mixture workability to a small extent. If EPS aggregate content is increased, the fresh concrete mix became rubbery, harsh, and difficult to place and compact [14].

The density of concrete containing varying amount of SPS aggregate is presented in Fig. 8. The densities for SPS Lightweight Aggregate Concretes (LWAC) were in the range of $1009-2074 \mathrm{~kg} / \mathrm{m}^{3}$. The SPS volume with the density of lower-than-natural aggregate in the mixes had a great effect on the concrete density. The density of the concretes decreased with 
the increase in SPS aggregate replacement $[14,19]$. The concrete with $100 \%$ SPS aggregate was shown to produce a LWAC that can float on water. As we know the density of concrete significantly affects the mechanical properties of concrete. The density of SPS aggregate was much less than that of natural aggregate.

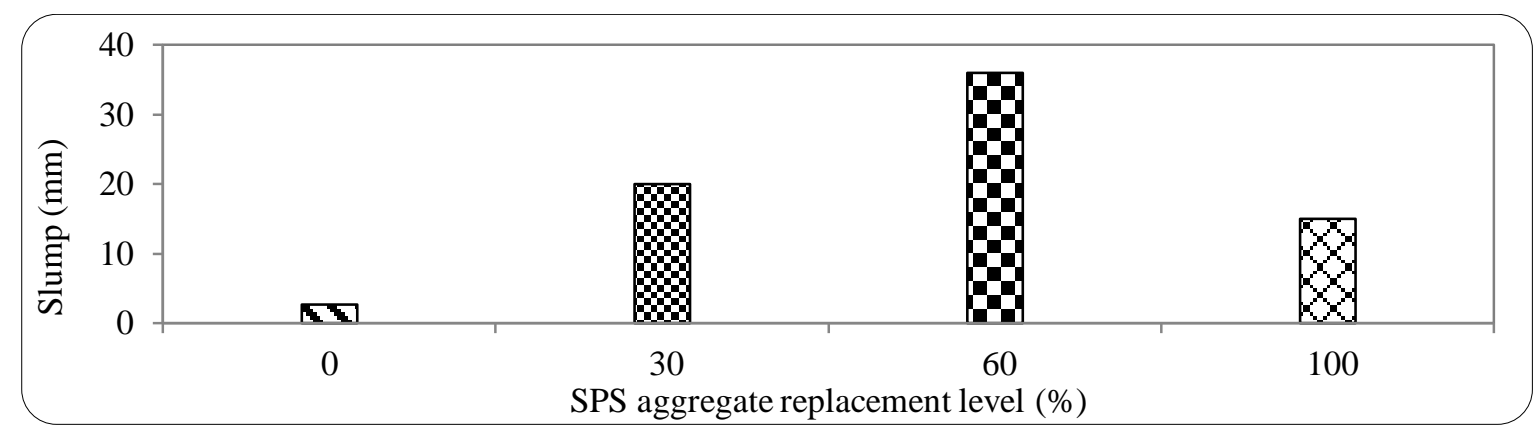

Fig. 7: Slump values of concrete mixes containing varying amounts of SPS aggregate

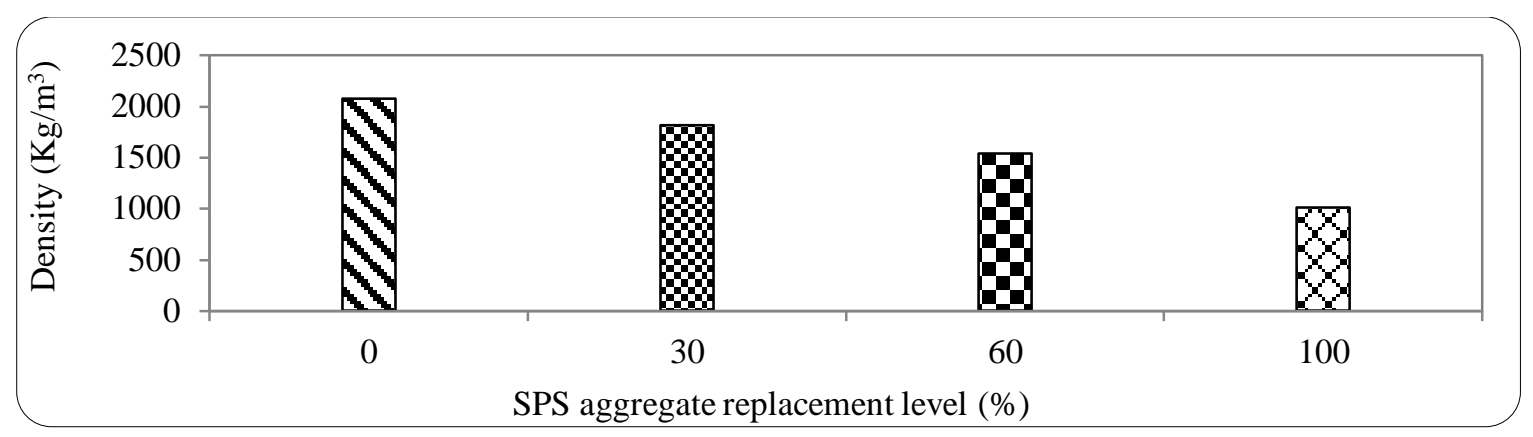

Fig. 8: Densities of concrete mixes containing varying amounts of SPS aggregate

\subsection{Compressive Strength}

The compressive strength of concrete containing varying amounts of SPS aggregate at 28day curing period is presented in Table 5. The results show that the incorporation of SPS aggregates caused a reduction in the compressive strength of concrete depending on the level of replacement with natural aggregate. The compressive strength of the concretes decreased between 29-78\% compared to the control concrete. According to the study [20] Lightweight Concretes (LWC) can be produced with an oven-dry density range of approximately 300$2000 \mathrm{~kg} / \mathrm{m}^{3}$ and with corresponding cube compressive strengths from approximately 1 to over $60 \mathrm{MPa}$. In the present study, a LWC containing a novel Lightweight Aggregate (LWA) called SPS has been produced with an oven-dry density of 1009-2074 kg/m $\mathrm{m}^{3}$ and cube compressive strength of 4.56-16.66 MPa. 
Table 5: Compressive strength of concrete containing varying amounts of SPS aggregate

\begin{tabular}{lll}
\hline Mix & SPS (\%) & Compressive Strength (MPa) \\
\hline 5 & 0 & 16.66 \\
6 & 30 & 16.43 \\
7 & 60 & 9.97 \\
8 & 100 & 4.56 \\
\hline
\end{tabular}

\subsection{Flexural Behaviour}

As previously stated in the methodology, the beams were tested as a simply supported beam under a point loading test. For each test, two beams with the same SPS aggregate content and reinforcement type were prepared. The beams were painted white to make cracks easier to detect.

\subsubsection{Deflection of Beams}

\subsubsection{Effect of SPS aggregate}

Fig. 9 shows the load-deflection curves for beams containing 0 (control), 30, 60 and 100\% SPS aggregate for beams with a) 2 steel bars, b) 3 steel bars and c) 2 steel bars + shear reinforcement. Generally, for all beams the load tended to increase sharply and linearly until the first crack appeared with a small increase in deflection. The first cracks were mainly influenced by the concrete's flexural strength, probably due to the low elastic modulus of SPS concretes and their high degree of compressibility compared with the control concrete. The cracks observed in SPS concretes were less wide and finer than in control concrete [13]. The slope of the load-deflection curves decreased after the first crack has occurred and the relationship was still approximately linear until the steel started yielding. Beyond the yield point there was a large increase in deflection associated with a small increase in load. The experimental results also suggest that the incorporation of SPS aggregate had an effect on the load deflection behaviour. Generally, as the replacement levels of SPS aggregate in mixtures increased, the deflection also increased, which was largely consistent for all three types of reinforcements. The increase in deflection is an indication of increased ductility. The presence of SPS tends to reduce the failure loads. It can be interpreted that EPS beads (80\%) in the SPS aggregate resulted in a substantial decrease in the concrete toughness [21]. For example, the load at the failure point is lower for beams containing SPS and the higher the SPS aggregate 
content, the lower the load. However, the deflection of $100 \%$ SPS mixtures is higher than that of other mixtures $(0,30$ and $60 \%$ SPS ) for all 3 different types of reinforcement.

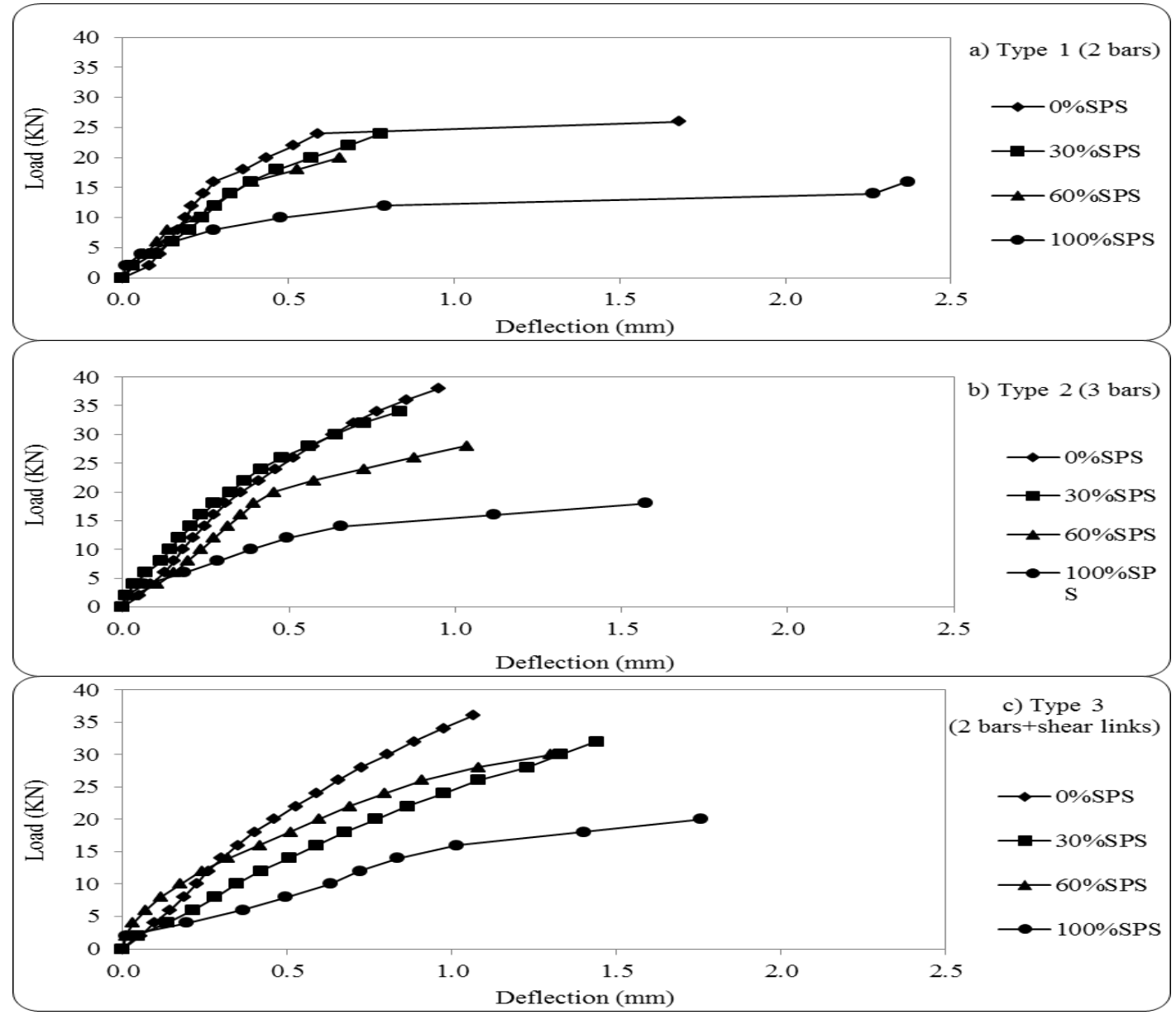

Fig. 9: Load-deflection curves for concrete beams containing varying amounts of SPS aggregate for a) 2 bars, b) 3 bars and c) 2 bars + shear links reinforcement

\subsubsection{Effect of reinforcement type}

Fig. 10 shows the load-deflection curves for beams with different types of reinforcement (2 steel bars, 3 steel bars and 2 steel bars + shear reinforcement) containing a) 0\% SPS (control), b) $30 \%$ SPS, c) $60 \%$ SPS and d) $100 \%$ SPS aggregate. As the load increased, deflections also increased and it was observed that the beams with $2 \varnothing 8$ tension reinforcement + shear links deflected more under smaller loads as opposed to beams with $2 ø 8$ and $3 ø 8$ tension reinforcements without shear links. For example, at $10 \mathrm{kN}$ load, the deflection for beams containing varying amounts of SPS aggregate and reinforced with $2 \varnothing 8$ bars + shear links was in the range of $0.18-0.63 \mathrm{~mm}$, whereas for the beams with $2 \varnothing 8$ and $3 \varnothing 8$ tension reinforcements, the deflection was in the range of $0.19-0.48 \mathrm{~mm}$ and $0.14-0.39 \mathrm{~mm}$, respectively. This is consistent with the findings of researchers [22] which investigated the flexural behaviour of phyllite LWA and reported that the beams with less reinforcement 
deflected more under smaller loads than beams with more reinforcement. It was also observed that the beams with $3 ø 8$ tension reinforcement without shear reinforcement (links) deflected less.

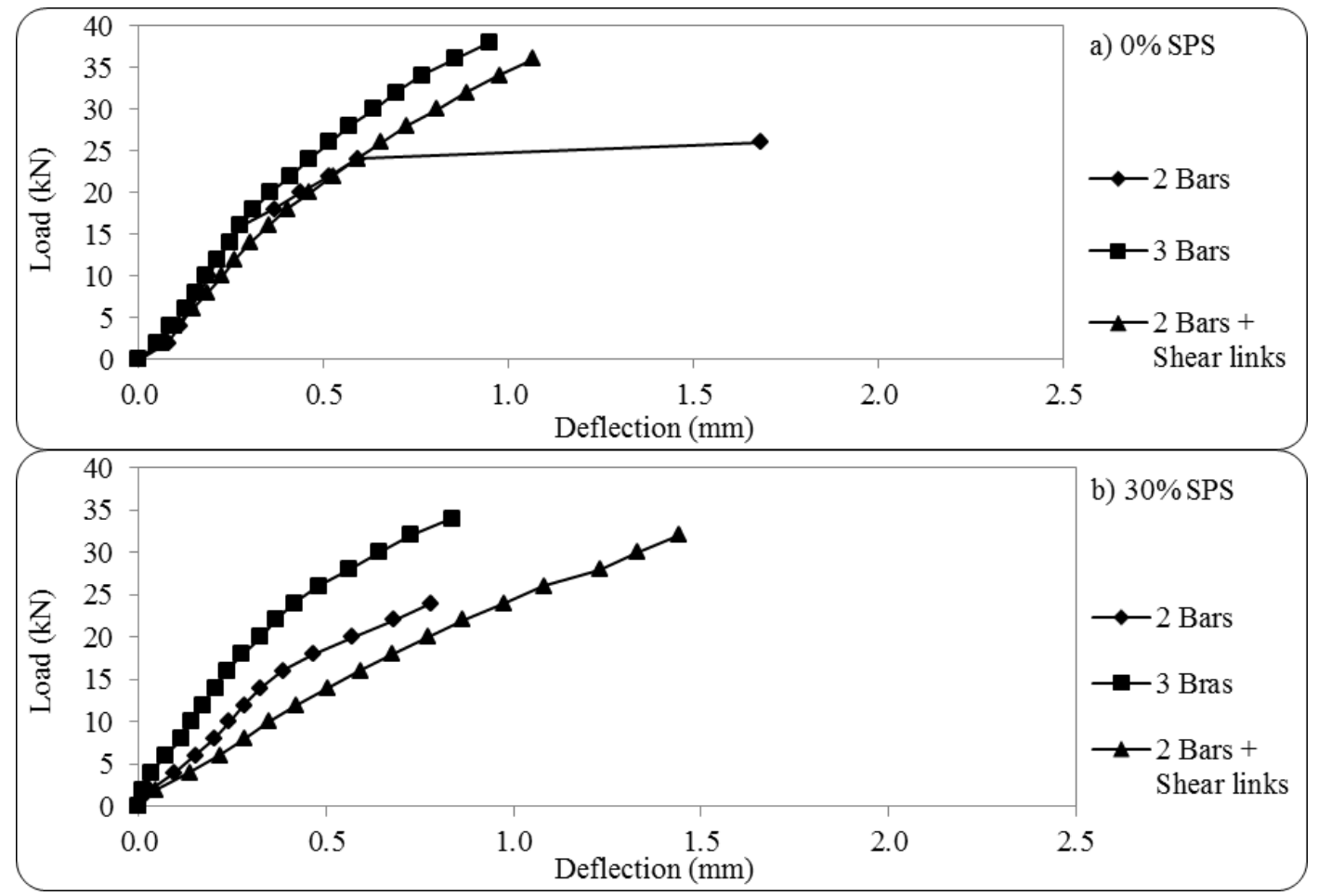




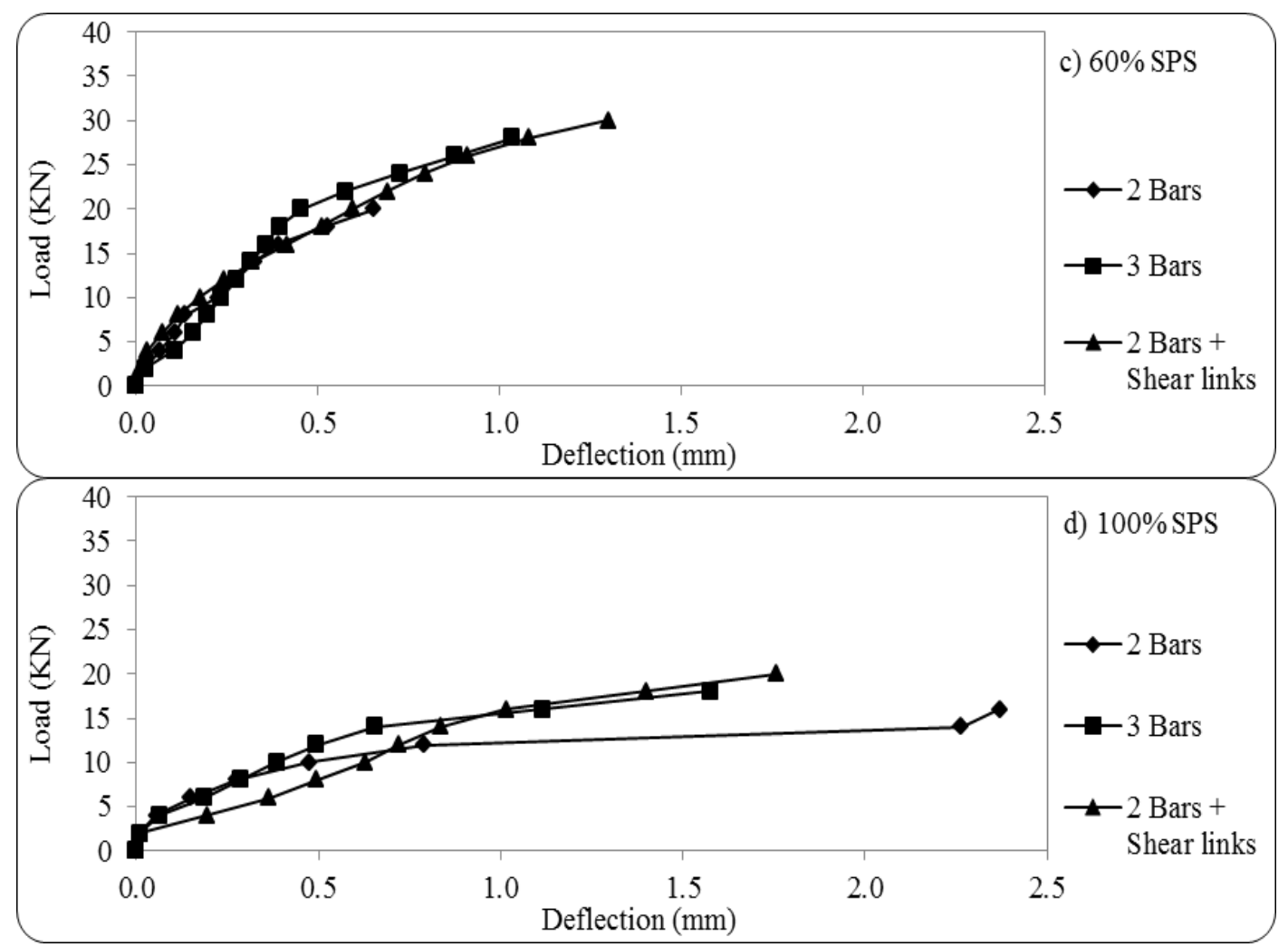

Fig. 10: Load-deflection curves for concrete beams with different reinforcements for a) $0 \%$ SPS, b) $30 \%$ SPS, c) $60 \%$ SPS and d) $100 \%$ SPS

\subsubsection{Mode of Failure}

Fig. 11 shows the load at first crack for beams containing varying amounts of SPS aggregate for different types of reinforcement. For Type 1 reinforcement ( 2 steel bars), as the SPS content increased, the load $(18 \mathrm{kN})$ at which the first crack appeared was the same for control, $30 \%$ and $60 \%$ SPS replacements, and decreased to $10 \mathrm{kN}$ for $100 \%$ SPS aggregate, indicating that the tensile strength of concrete decreases more for high replacement levels (100\% SPS). For Type 2 reinforcement (3 steel bars) as the SPS content increased, the load $(24 \mathrm{kN})$ at which the first crack appeared was the same for control and 30\% SPS aggregate, but decreased to $22 \mathrm{kN}$ for $60 \%$ SPS and to $10 \mathrm{kN}$ for $100 \%$ SPS replacements. For Type 3 reinforcement ( 2 steel bars + shear links) as the SPS content increased, the load $(16 \mathrm{kN})$ at which the first crack appeared decreased. However, the first crack load $(14 \mathrm{kN})$ for concrete with 30 and $60 \%$ SPS content was the same and for $100 \%$ SPS was $12 \mathrm{kN}$. It is well known that a decrease in compressive strength leads to a decrease in tensile strength. The results suggest that up to $60 \%$ replacement level, the benefit to the first crack loads was not greatly affected by increasing the content of SPS aggregate, but it was greatly affected at $100 \%$ replacement. For example, the decrease in the first crack load for the concrete with $60 \%$ SPS replacement was 0,8 and $12.5 \%$ for reinforcement types 1 ( 2 bars), 2 ( 3 bars) and 3 ( 2 bars + 
shear links), respectively compared to the control concrete. The results shown in Fig. 11 indicate that the load at first crack for concrete beams containing 0, 30 and $60 \%$ SPS aggregate with 3 steel bars is higher than the other types of reinforcement, but for concrete beams containing $100 \%$ SPS aggregate with 2 bars + shear links, the first crack load is the highest, which shows the effect of stirrups at first crack load for concretes with high contents of LWA.

The cracks forming on the surface of the beam were mostly flexural cracks. For the beams containing varying amounts of SPS aggregate with $2 ø 8$ steel bars as tension reinforcement, initial cracking occurred at about $69-90 \%$ of its failure load, whereas for the beams with $3 \varnothing 8$ steel bars as tension reinforcement and $2 \varnothing 8$ bars + shear links, initial cracking occurred at 62$84 \%$ and $36-60 \%$ of its failure loads, respectively. This indicates that for lower reinforcement ratios, the first crack occurs at a higher percentage of the failure load as shown in Fig. 12. This view is consistent with the findings of researchers [12] who found that different ratios of reinforcement have an influence on the initiation of the first crack with regard to its failure load. With continuous load increments, the cracks started to take a diagonal shape towards the compression zone of the beams. In general, it can be observed that SPS aggregate concrete beams demonstrate similar behaviour to that of other lightweight concrete beams such as those observed by earlier studies [12, 23, 24] on lightweight oil palm shell concrete beams. However, for SPS concrete to be accepted for structural applications, further investigations need to be conducted.

The experimental results of the present work also show that there is a decrease in the beams' failure loads with an increase in SPS aggregate content for all three reinforcement types as shown in Fig. 13. The failure load for concrete beams with 2 bar tension reinforcement and containing 0,30, 60 and 100\% SPS was 26.08, 22.58, 20.01 and $14.03 \mathrm{kN}$, respectively. The failure load for concrete beams with 3 bar tension reinforcement and containing 0, 30, 60 and 100\% SPS was 37.13, 32.84, 25.95 and $15.10 \mathrm{kN}$, respectively. The failure load for concrete beams with 2 bar tension reinforcement + shear links and containing 0, 30, 60 and 100\% SPS was 36.32, 30.91, 27.75 and $17.75 \mathrm{kN}$, respectively. The results obtained show that the beams with Type 1 ( 2 bars) reinforcement recorded the lowest failure load for all SPS replacement levels compared with other types of reinforcement. The beams' failure loads with Type 2 ( 3 bars) reinforcement are higher than types 1 ( 2 bars) and 3 ( 2 bars + shear links) at 0 and 30\% SPS contents, indicating enhancement of the bond strength between the concrete and steel for lower SPS replacement levels. The results also show that 
the beams' failure loads in Type 3 ( 2 bars + shear links) are higher than types 1 (2 bars) and 2 (3 bars) at 60 and 100\% SPS content, indicating the positive effect of shear reinforcement (stirrups); thus compensating for the low compressive strength of SPS and enhancing the bond strength between the concrete and steel for higher SPS replacement levels. Generally, decreasing tension reinforcements (from 3 bars to 2 bars) and using shear links, the failure load decreased for control and 30\% SPS concretes but increased for 60 and 100\% SPS.

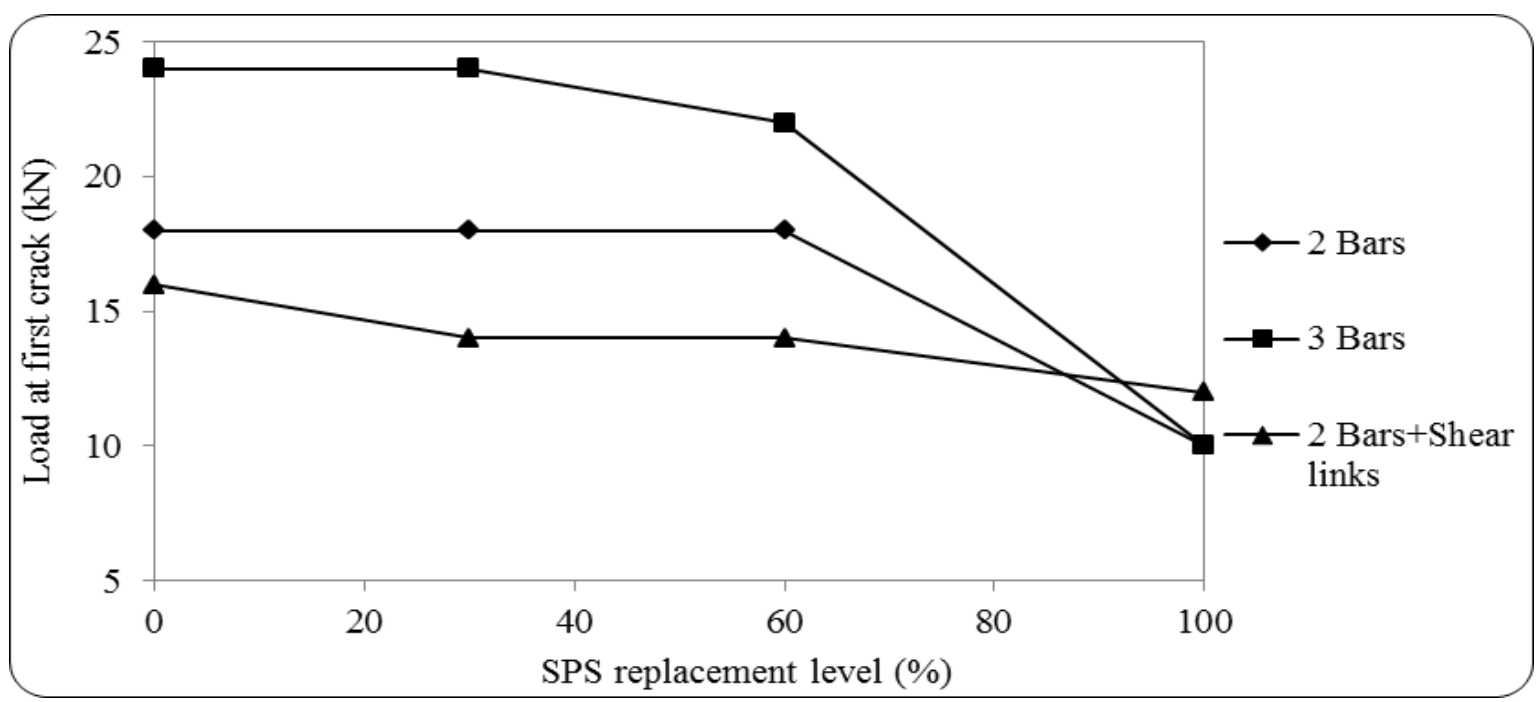

Fig. 11: Load at first crack of concrete beams containing varying amounts of SPS aggregate with different reinforcements

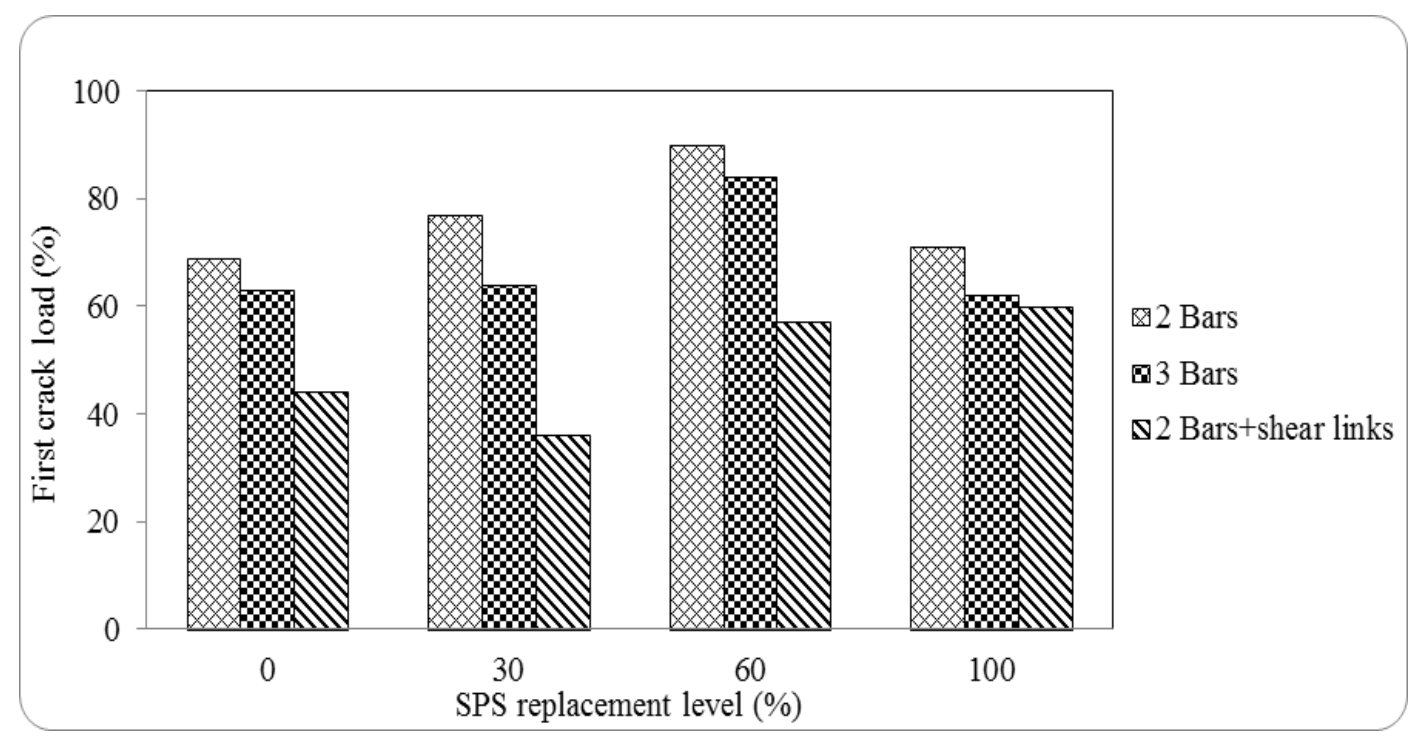

Fig. 12: Percentage of first crack load to failure load of concrete beams containing varying amounts of SPS aggregate with different types of reinforcement 


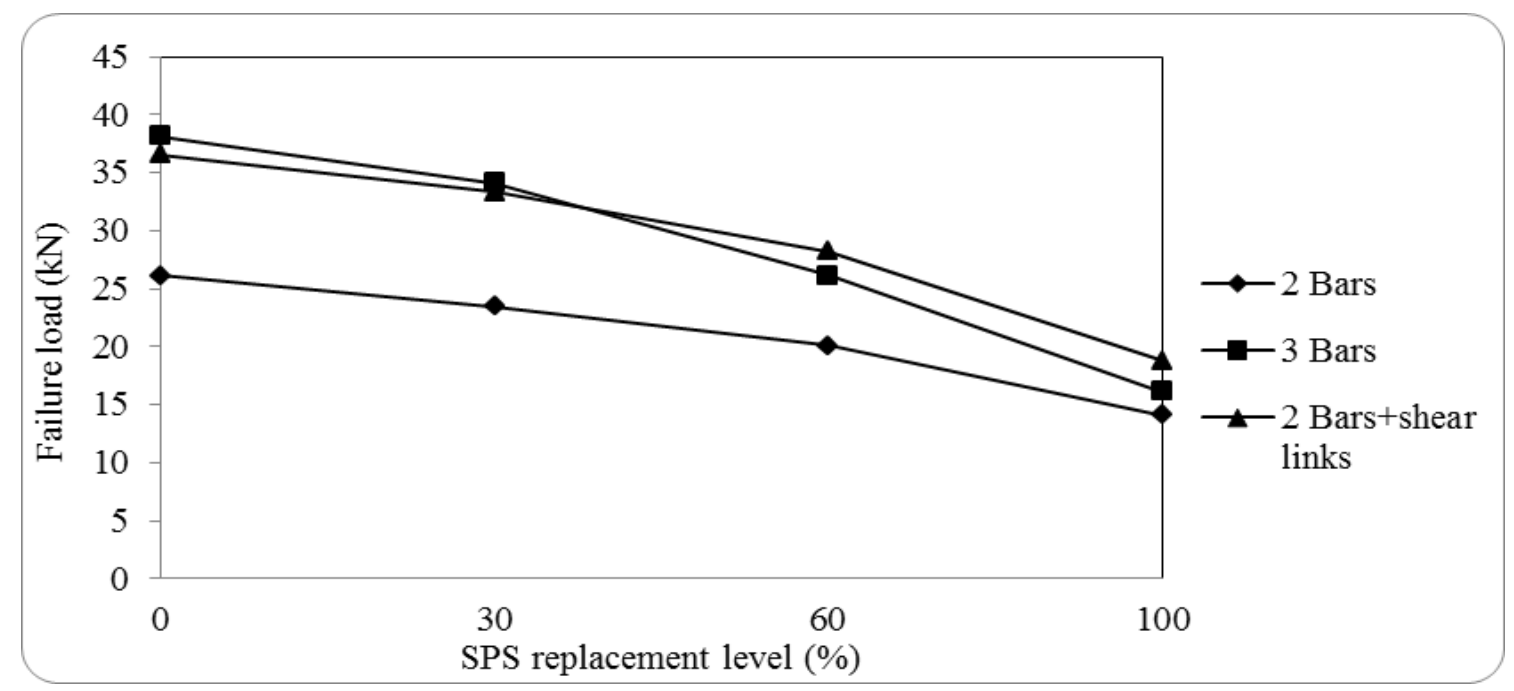

Fig. 13: Failure load of concrete beams containing varying amounts of SPS aggregate with different types of reinforcement

Figs 14 - 20 show the mode of failure for concrete beams containing varying amounts of SPS aggregate (0, 30, 60 and 100\% SPS) with different types of reinforcment ( 2 bars, 3 bars and 2 bars + shear links). The beams failed in the form of a diagonal crack which started in the tension side of the beam and, with progressive loads, propagated towards the compression side under the loads. The mode of failure for concrete beams containing varying amounts of SPS with different types of reinforcement was shear failure, except for beams with 2 bars + shear links where it was shear/compression (concrete crushing in the compression zone) failure. The yielding of the tensile reinforcement happened before the crushing of the compression concrete in the pure bending zone. A similar observation has been reported by Teo et al. (2006). For concrete beams containing 100\% SPS the failure occurred near or at the support point.

\subsubsection{Strain Distribution}

Figs. 21 - 27 show the strain distribution diagrams and Figs. 28 and 29 show the neutral axis depth for concrete containing varying amounts of SPS with different types of reinforcement. The strain distribution for load increments and the corresponding change in the neutral axis position was measured using a DEMEC strain gauge at various positions along the depth of the beam. The strain values of beams with different types of reinforcement increased with an increase in the SPS content. Generally, the neutral axis depth for concrete beams containing $0,30,60$ and $100 \%$ with different types of reinforcement was between 57 95, 60-95, 72-95 and 92-105mm; this decreased with an increase in SPS content in concrete. 
As the load increased, the neutral axis shifted upwards towards the compression zone, which means the depth of the compression zone decreased for all concrete beams and types of reinforcement except for $100 \%$ SPS beams with 3 bars. The neutral axis depth for $100 \%$ SPS beams reinforced with 3 bars shifted downwards towards the tension zone, which means it increased and recorded the maximum depth compared with other concrete beams. The change in neutral axis position towards the compression zone indicates that the tension zone of the beam increased and the compression zone decreased.

\section{Conclusions}

The results show that as the replacement levels of SPS aggregate in mixtures increased, the deflection also increased, which was consistent for all three types of reinforcements (2 bars, 3 bars and 2 bars + shear links). The increase in deflection is an indication of increased ductility. The mode of failure for concrete beams containing varying amounts of SPS with different types of reinforcement was shear failure, except for beams with 2 bars + shear links which was shear/compression (concrete crushing in the compression zone) failure. In general, it is possible to use SPS lightweight aggregate in concrete based applications and the performance is comparable to other types of LWAC currently used around the world. The concrete containing 30\% SPS aggregate with $16.43 \mathrm{MPa}$ strength and $1814 \mathrm{~kg} / \mathrm{m}^{3}$ density can comply with the structural lightweight aggregate concrete applications (e.g. beams) requirements of RILEM classification. The engineering properties of SPS concrete can be improved by decreasing W/C ratio and adding super-plasticiser, adding natural coarse aggregate, and increasing the amount of cement content. However, sustainability issues (economic-environment-social) should be taken into consideration.

The main recommendation for further possible work is to investigate the resistance of SPS aggregate to chemicals and how the clay content in the SPS aggregate affects the final concrete strength using different methods of curing.

\section{Acknowledgments}




\section{References}

[1] Bhutta, M. A. R., Ohama, Y. and Tsuruta, K. (2011) Strength properties of polymer mortar panels using methyl methacrylate solution of waste expanded polystyrene as binder, Construction and Building Materials, Elsevier Ltd, 25(2), pp. 779-784, [online] Available from: http://linkinghub.elsevier.com/retrieve/pii/S0950061810003739 (Accessed 3 May 2013).

[2] Glenn, G. and Orts, W. (2001) Properties of starch-based foam formed by compression/explosion processing, Industrial Crops and Products, 13(2), pp. 135-143, [online] Available from: http://linkinghub.elsevier.com/retrieve/pii/S0926669000000601 (Accessed 10 May 2013).

[3] Polymelt, (2013) Polystyrene recycling. Available from: http://www.polymeltltd.co.uk (Accessed 10 May 2013).

[4] Noguchi, T., Miyashita, M., Inagaki, Y.,Watanabe, H., (1998) A new recycling system for expanded polystyrene using a natural solvent. Packaging Technology Science 11, 19.

[5] Guan, H., Liu, S., Duan, Y. and Zhao, Y. (2007) Investigation of the electromagnetic characteristics of cement based composites filled with EPS, Cement and Concrete Composites, 29(1), pp. 49-54, [online] Available from: http://linkinghub.elsevier.com/retrieve/pii/S0958946506001600 (Accessed 3 May 2013).

[6] Miskolczi, N., Bartha, L. and Deák, G. (2006) Thermal degradation of polyethylene and polystyrene from the packaging industry over different catalysts into fuel-like feed stocks, Polymer Degradation and Stability, 91(3), pp. 517-526, [online] Available from: http://linkinghub.elsevier.com/retrieve/pii/S0141391005003836 (Accessed 28 May 2013).

[7] Amianti, M. and Botaro, V. R. (2008) Recycling of EPS: A new methodology for production of concrete impregnated with polystyrene (CIP), Cement and Concrete Composites, 30(1), pp. 23-28, [online] Available from: http://linkinghub.elsevier.com/retrieve/pii/S0958946507000911 (Accessed 3 May 2013).

[8] Asaad, J. N. and Tawfik, S. Y. (2011) Polymeric composites based on polystyrene and cement dust wastes, Materials \& Design, Elsevier Ltd, 32(10), pp. 5113-5119, [online] Available from: http://linkinghub.elsevier.com/retrieve/pii/S026130691100416X (Accessed 3 May 2013).

[9] Batayneh, Malek K., Marie, I. and Asi, I. (2008) Promoting the use of crumb rubber concrete in developing countries, Waste Management, 28(11), pp. 2171-2176, [online] Available from: http://linkinghub.elsevier.com/retrieve/pii/S0956053X07003327 (Accessed 21 May 2013).

[10] Kan, A. \& Demirboğa, R., (2009) A new technique of processing for waste-expanded polystyrene foams as aggregates. Journal of Materials Processing Technology, 209(6), pp.2994-3000. 
[11] Tang, W. C., Lo, Y., Nadeem, A., (2008). Mechanical and drying shrinkage properties of structural-graded polystyrene aggregate concrete. Cement and Concrete Composites, 30, pp. 403-409.

[12] Teo, D. C. L., Mannan, M. A. and Kurian, J. V. (2006) Flexural Behaviour of Reinforced Lightweight Concrete Beams Made with Oil Palm Shell (OPS), Journal of Advanced Concrete Technology, 4(3), pp. 459-468, [online] Available from: http://joi.jlc.jst.go.jp/JST.JSTAGE/jact/4.459?from=CrossRef (Accessed 10 May 2013).

[13] Tang, W. C., Balendran, R. V., Nadeem, a. and Leung, H. Y. (2006) Flexural strengthening of reinforced lightweight polystyrene aggregate concrete beams with nearsurface mounted GFRP bars, Building and Environment, 41(10), pp. 1381-1393, [online] Available from: http://linkinghub.elsevier.com/retrieve/pii/S0360132305002015 (Accessed 28 May 2013).

[14] Sabaa, B., \& Ravindrarajah, R. S., (1997) Engineering properties of lightweight concrete containing crushed expanded polystyrene waste. In: Materials research society, fall meeting, symposium MM, advances in materials for cementitious compos, Boston, USA; December 1997.

[15] British Standards Institution, BS EN 933-1., (1997). Tests for geometrical properties of aggregates. Part 1: Determination of particle size distribution - Sieving method.

[16] British Standards Institution, BS EN 12390-1:2012 Testing hardened concrete Part 1: Shape, dimensions and other requirements for specimens and moulds.

[17] British Standards Institution, BS EN 12350-2., (2009). Testing fresh concrete. Part 2: Slump-test.

[18] British Standards Institution, BS EN 12390-3., (2009). Testing hardened concrete. Part 3: Compressive strength of test specimens.

[19] Kan, A. and Demirboğa, R. (2007) Effect of cement and EPS beads ratios on compressive strength and density of lightweight concrete, Indian Journal of Engineering \& Materials Sciences, 14(April), pp. 158-162.

[20] Shafigh, P., Jumaat, M. Z., Mahmud, H. Bin and Hamid, N. A. A. (2012) Lightweight concrete made from crushed oil palm shell: Tensile strength and effect of initial curing on compressive strength, Construction and Building Materials, Elsevier Ltd, 27(1), pp. 252258, [online] Available from: http://linkinghub.elsevier.com/retrieve/pii/S0950061811004053 (Accessed 3 May 2013).

[21] Sadrmomtazi, a., Sobhani, J., Mirgozar, M. a. and Najimi, M. (2012) Properties of multistrength grade EPS concrete containing silica fume and rice husk ash, Construction and Building Materials, Elsevier Ltd, 35, pp. 211-219, [online] Available from: http://linkinghub.elsevier.com/retrieve/pii/S0950061812001262 (Accessed 3 May 2013).

[22] Adom-Asamoah, M. and Afrifa, R. O. (2011) Investigation on the flexural behaviour of reinforced concrete beams using phyllite aggregates from mining waste, Materials \& Design, Elsevier Ltd, 32(10), pp. 5132-5140, [online] Available 

January 2014).

[23] Alengaram, U. J. Jumaat, M. Z., and Mahmud, H. (2008) Ductility Behaviour of Reinforced Palm Kernel Shell Concrete Beams, European Journal of Scientific Research 23(3), pp. 406-420.

[24] Johnson Alengaram, U., Jumaat, M. Z., Mahmud, H. and Fayyadh, M. M. (2011) Shear behaviour of reinforced palm kernel shell concrete beams, Construction and Building Materials, Elsevier Ltd, 25(6), pp. 2918-2927, [online] Available from: http://linkinghub.elsevier.com/retrieve/pii/S0950061810007105 (Accessed 12 November 2013).

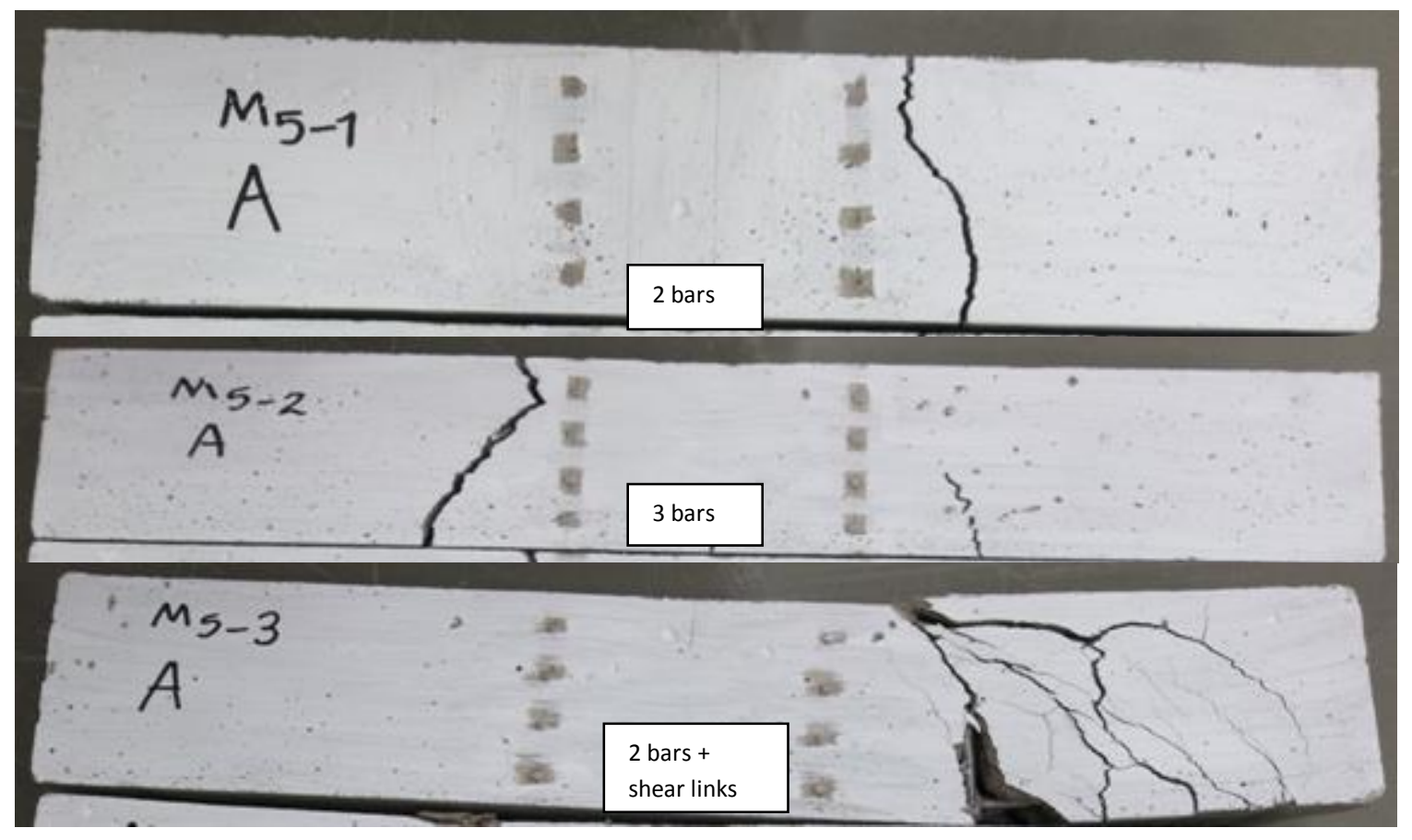


Fig. 14: Mode of failure of beams containing 0\% SPS (control) with 2 bars, 3 bars and 2 bars + shear links reinforcement

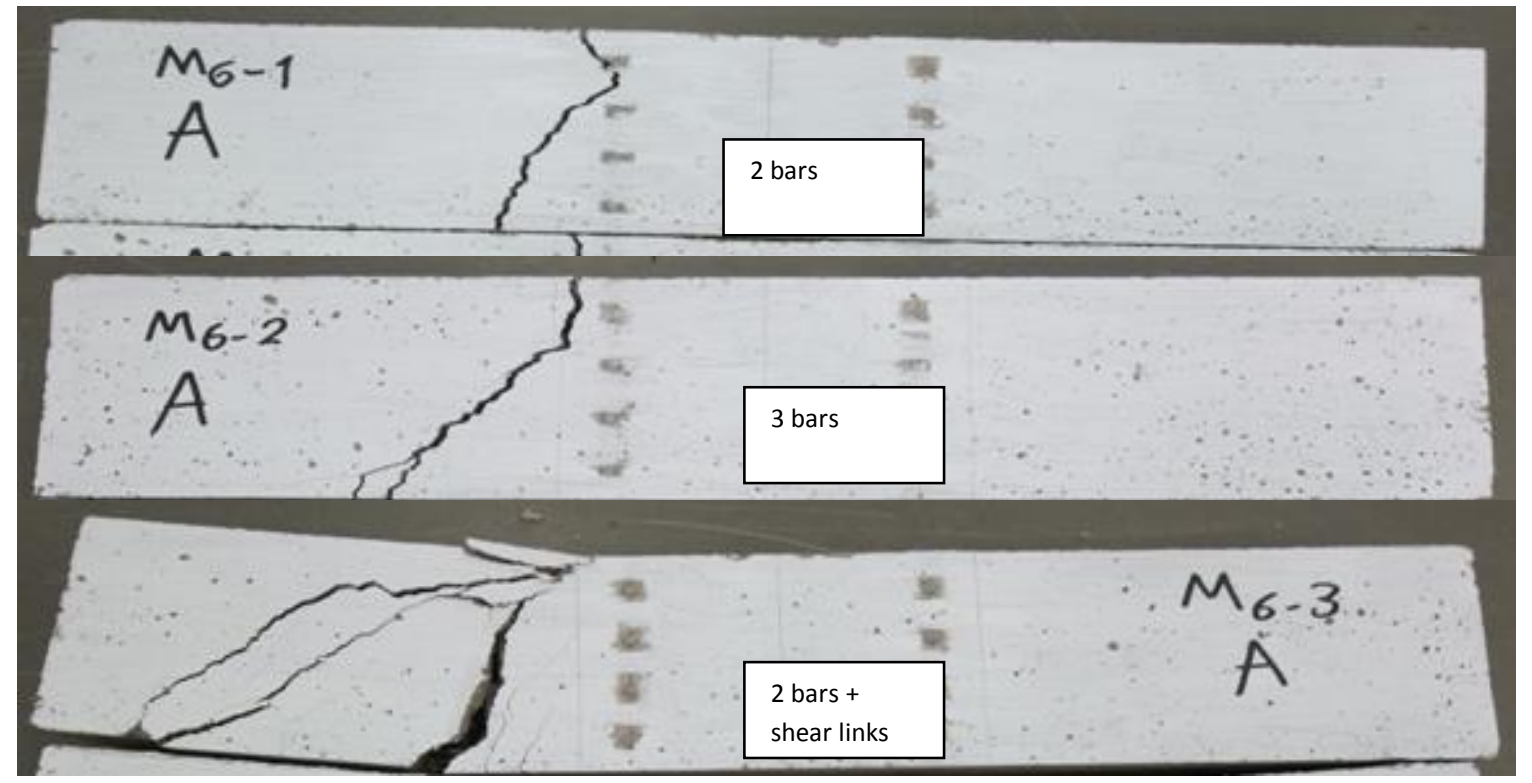

Fig. 15: Mode of failure of beams containing 30\% SPS with 2 bars, 3 bars and 2 bars + shear links reinforcement

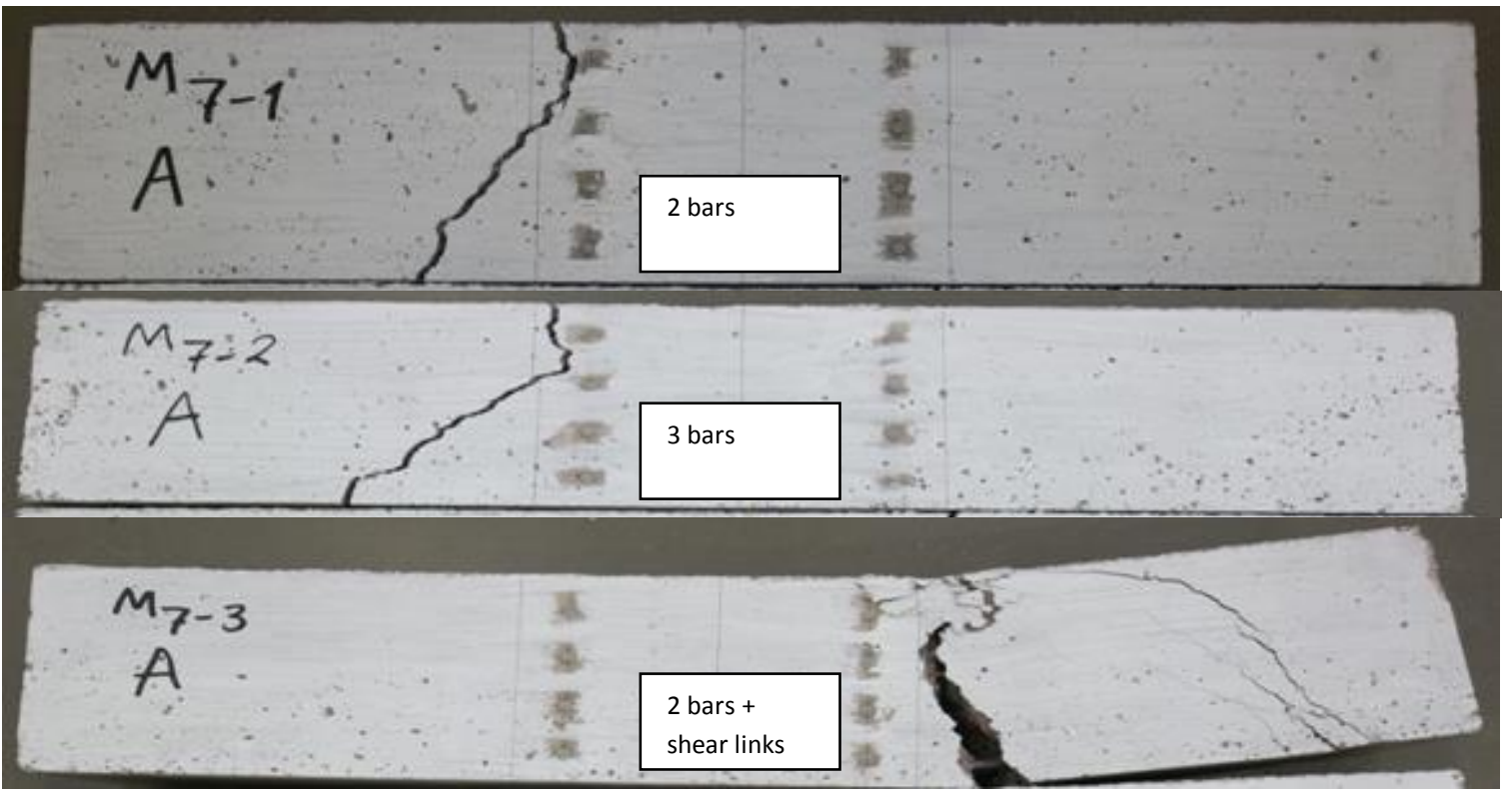

Fig. 16: Mode of failure of beams containing 60\% SPS with 2 bars, 3 bars and 2 bars + shear links reinforcement 


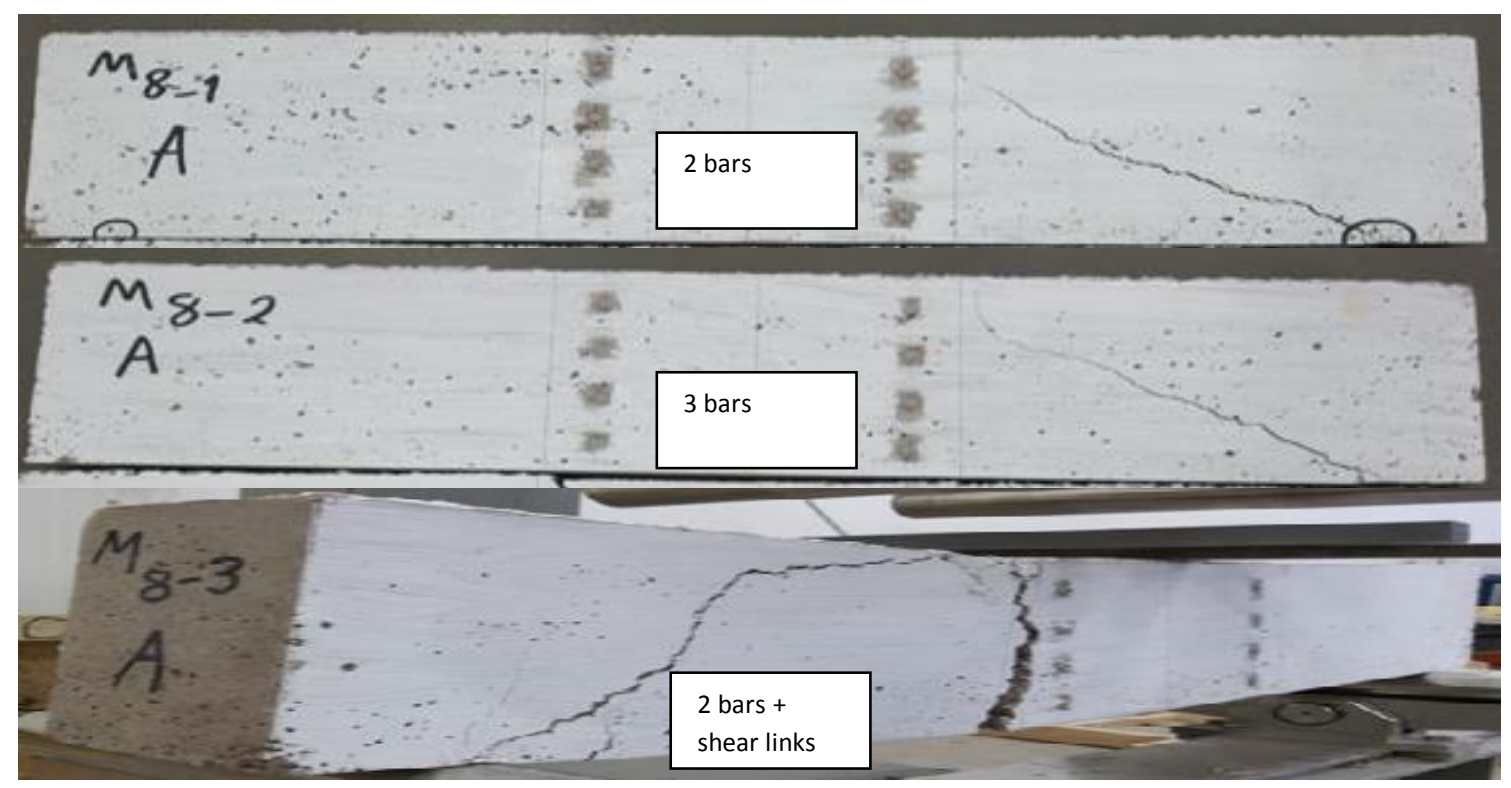

Fig. 17: Mode of failure of beams containing 100\% SPS with 2 bars, 3 bars and 2 bars + shear links reinforcement

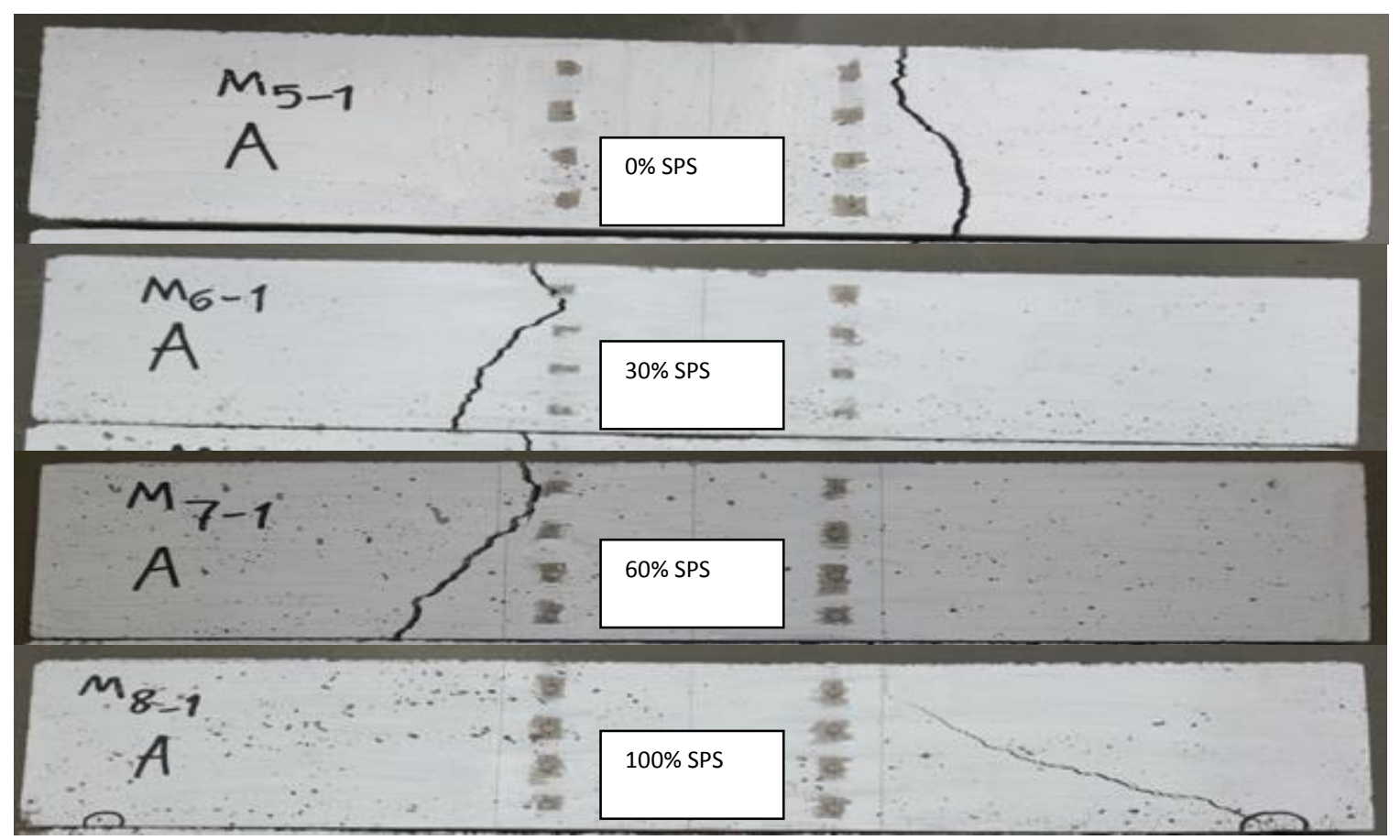

Fig. 18: Mode of failure of beams with 2 bars reinforcement containing 0, 30, 60 and 100\% SPS 


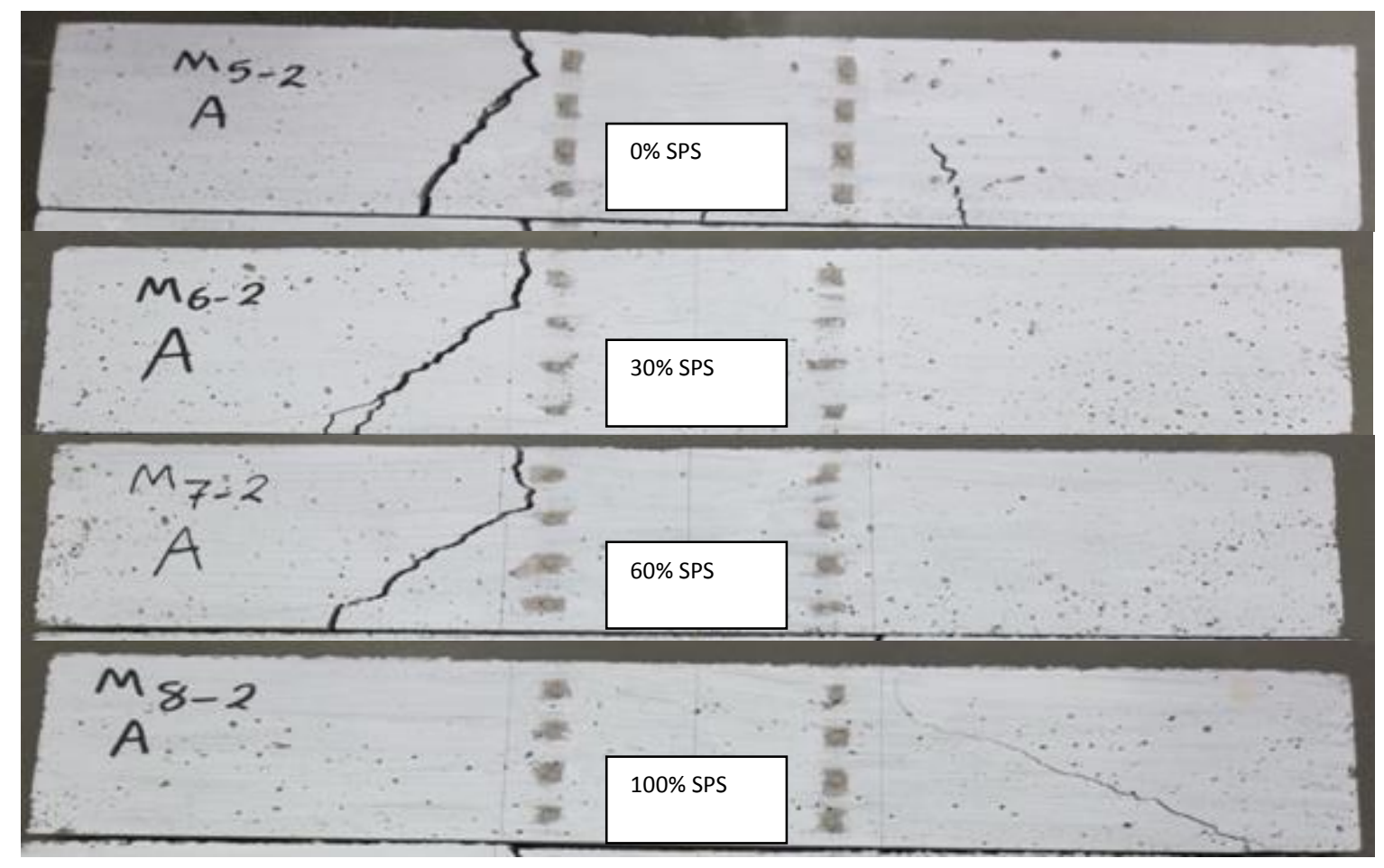

Fig. 19: Mode of failure of beams with 3 bars reinforcement containing 0, 30, 60 and 100\% SPS

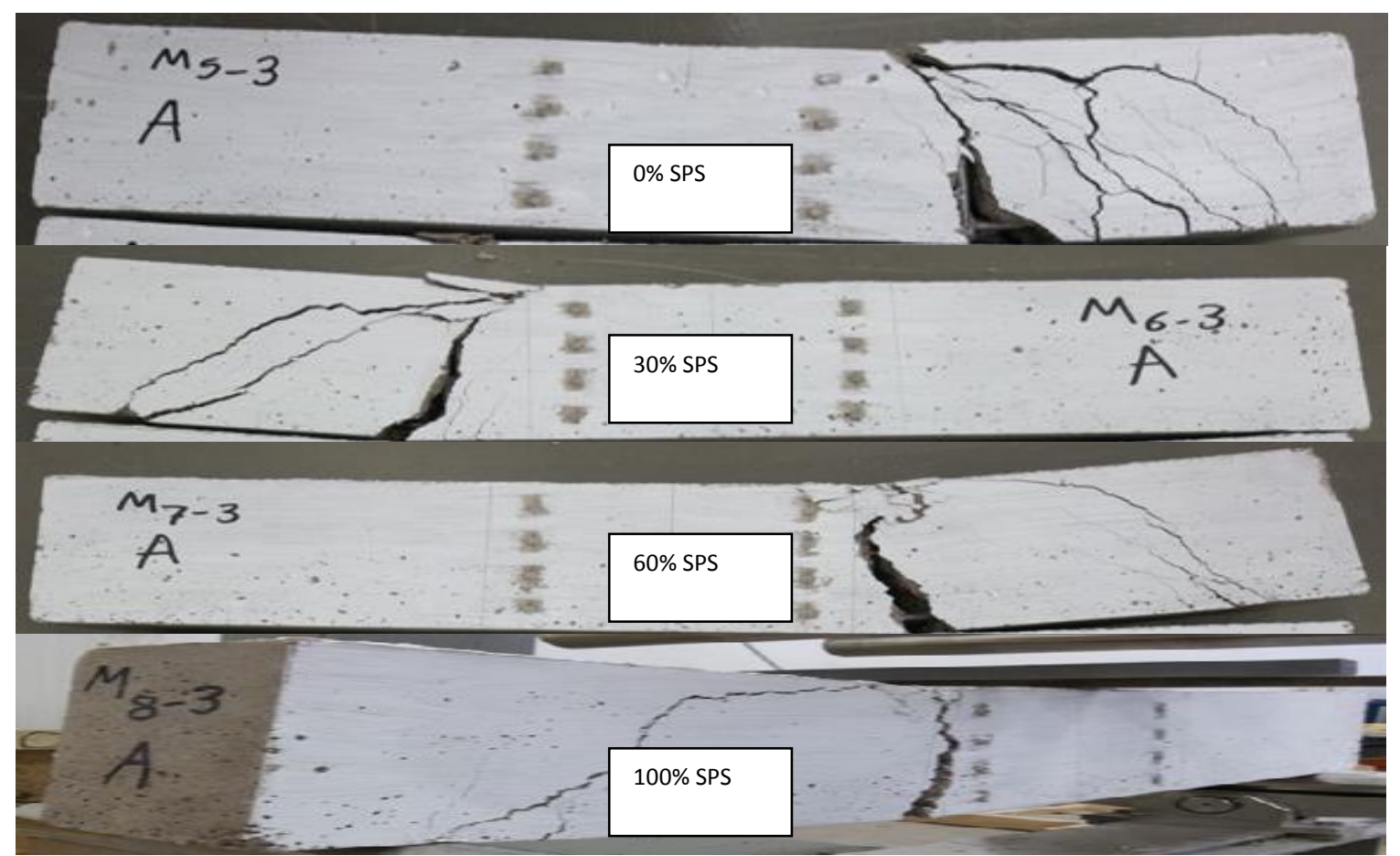

Fig. 20: Mode of failure of beams with 2 bars + shear links reinforcement containing 0, 30, 60 and 100\% SPS 


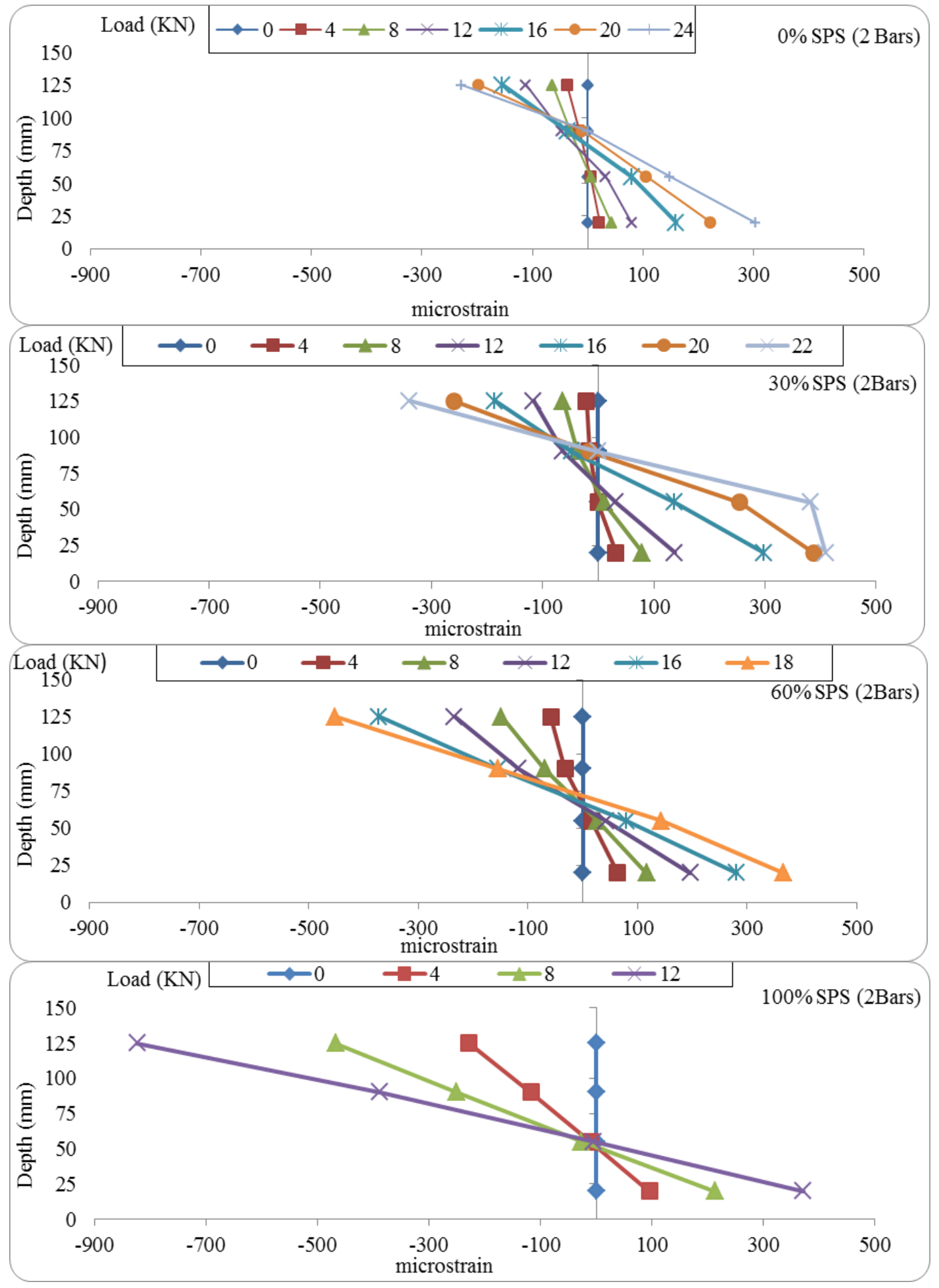

Fig. 21: Strain distribution of beams containing varying amounts of SPS aggregate with 2 bars reinforcement 


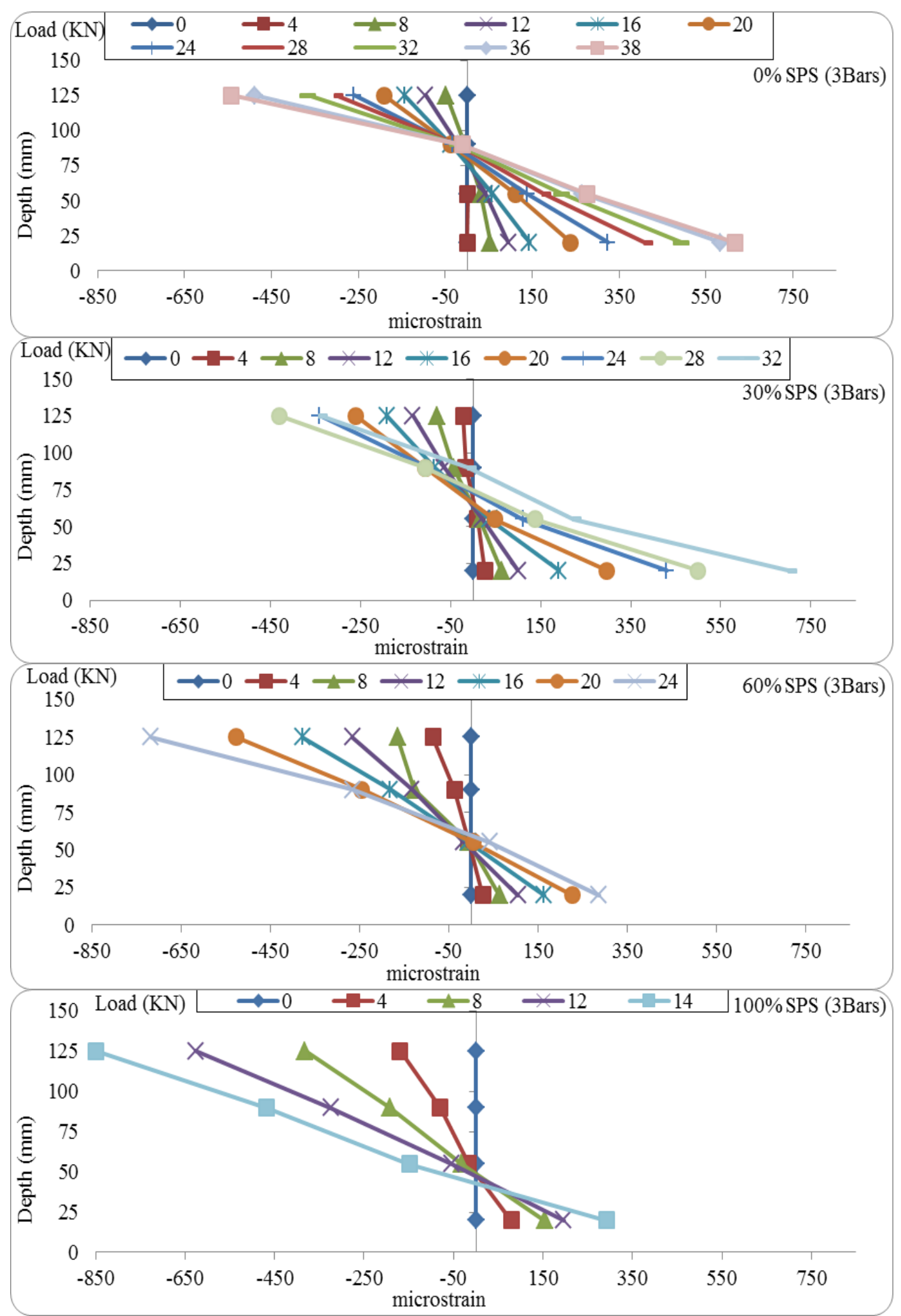

Fig. 22: Strain distribution of beams containing varying amounts of SPS aggregate with 3 bars reinforcement 


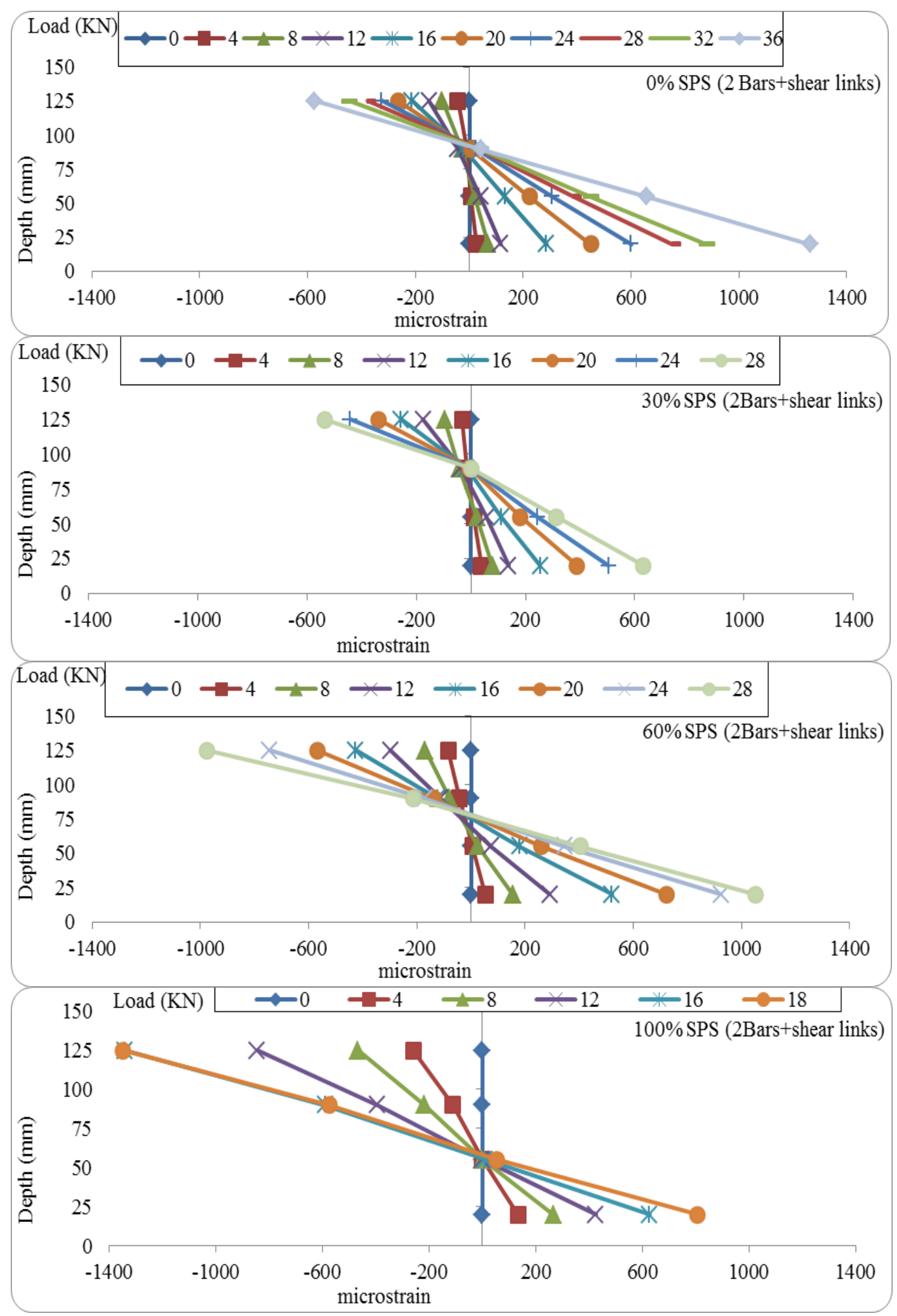

Fig. 23: Strain distribution of beams containing varying amounts of SPS aggregate with 2 bars + shear links reinforcement 


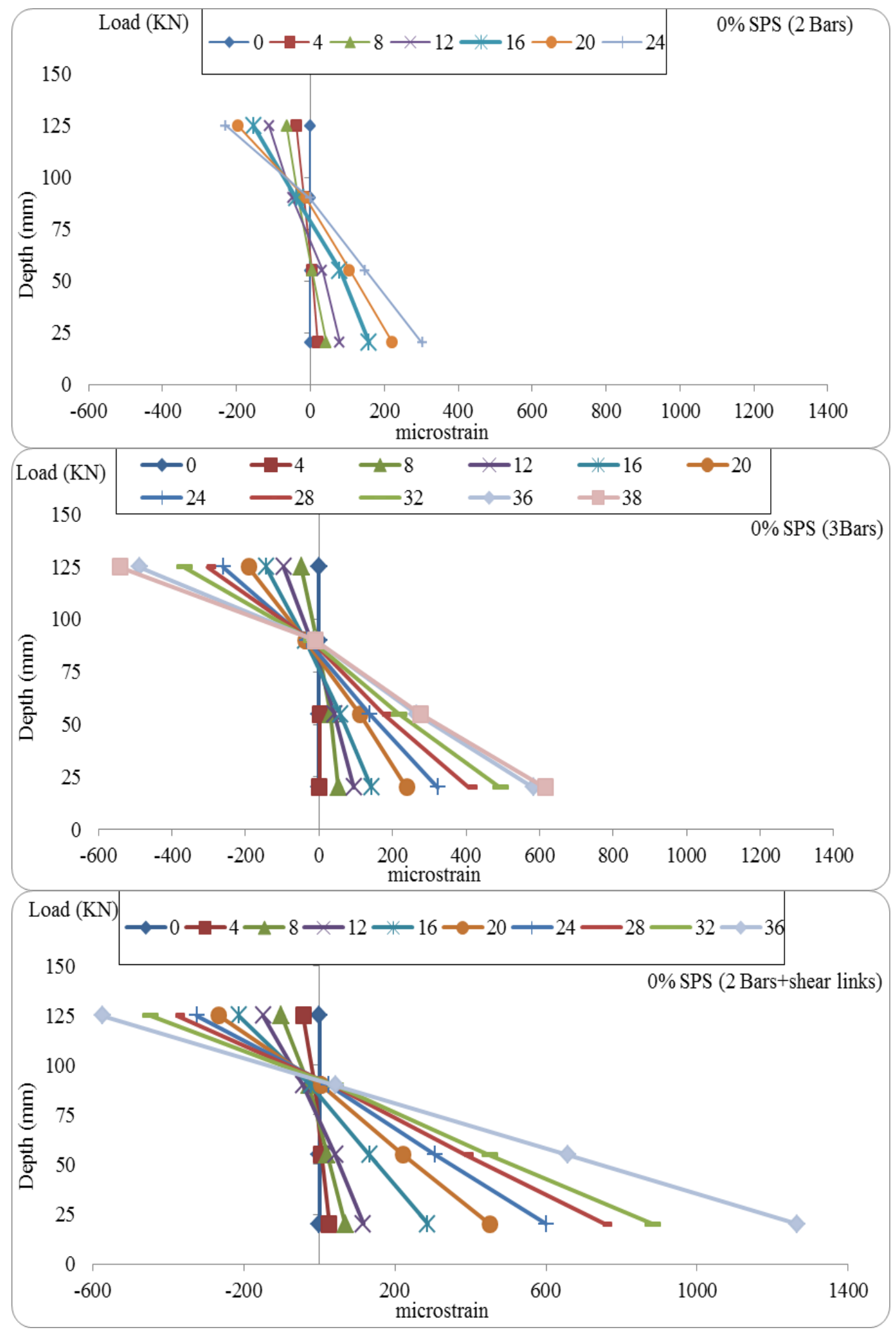

Fig. 24: Strain distribution of beams containing 0\% SPS aggregate (control) with different reinforcements 


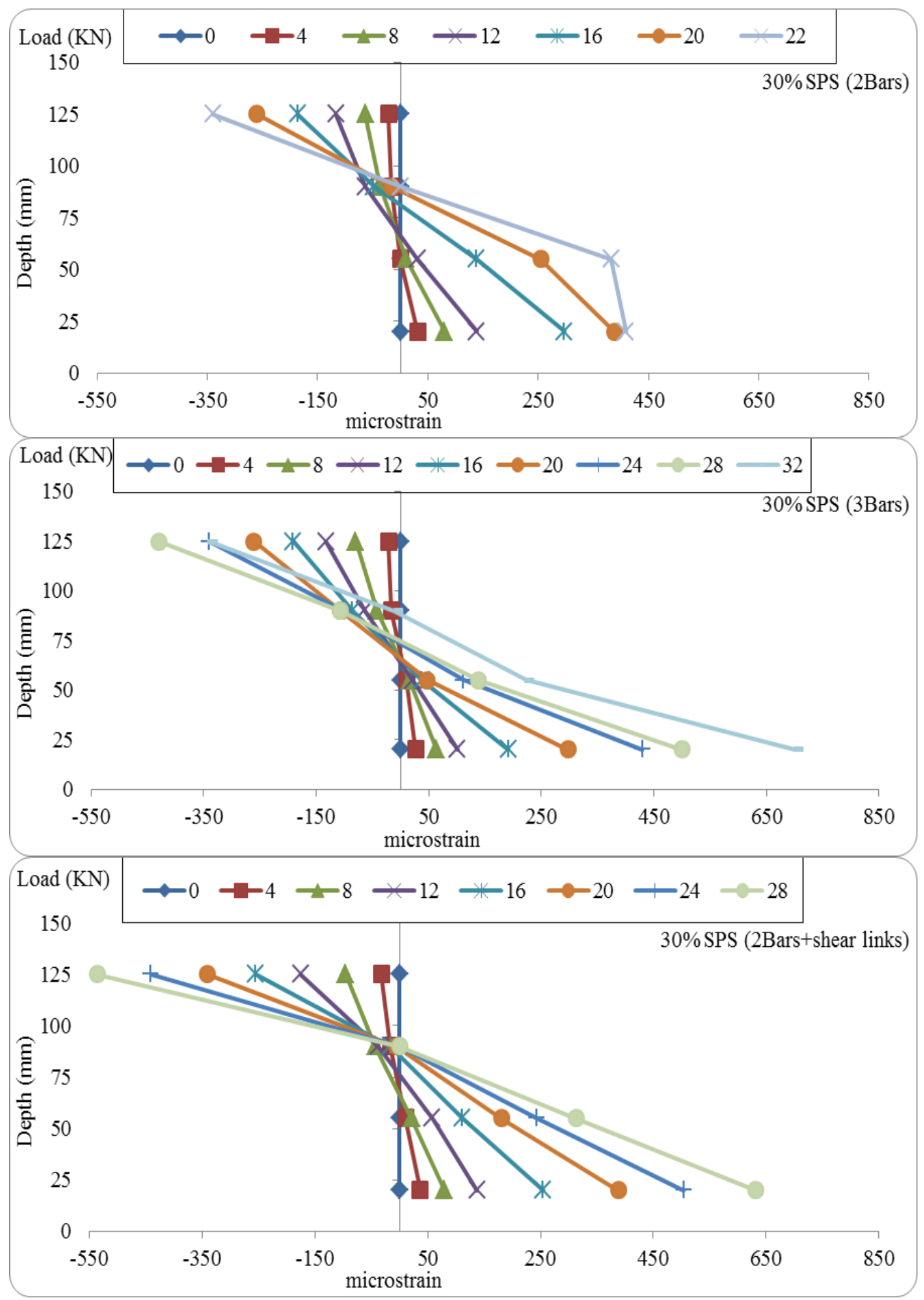

Fig. 25: Strain distribution of beams containing 30\% SPS aggregate with different reinforcements 


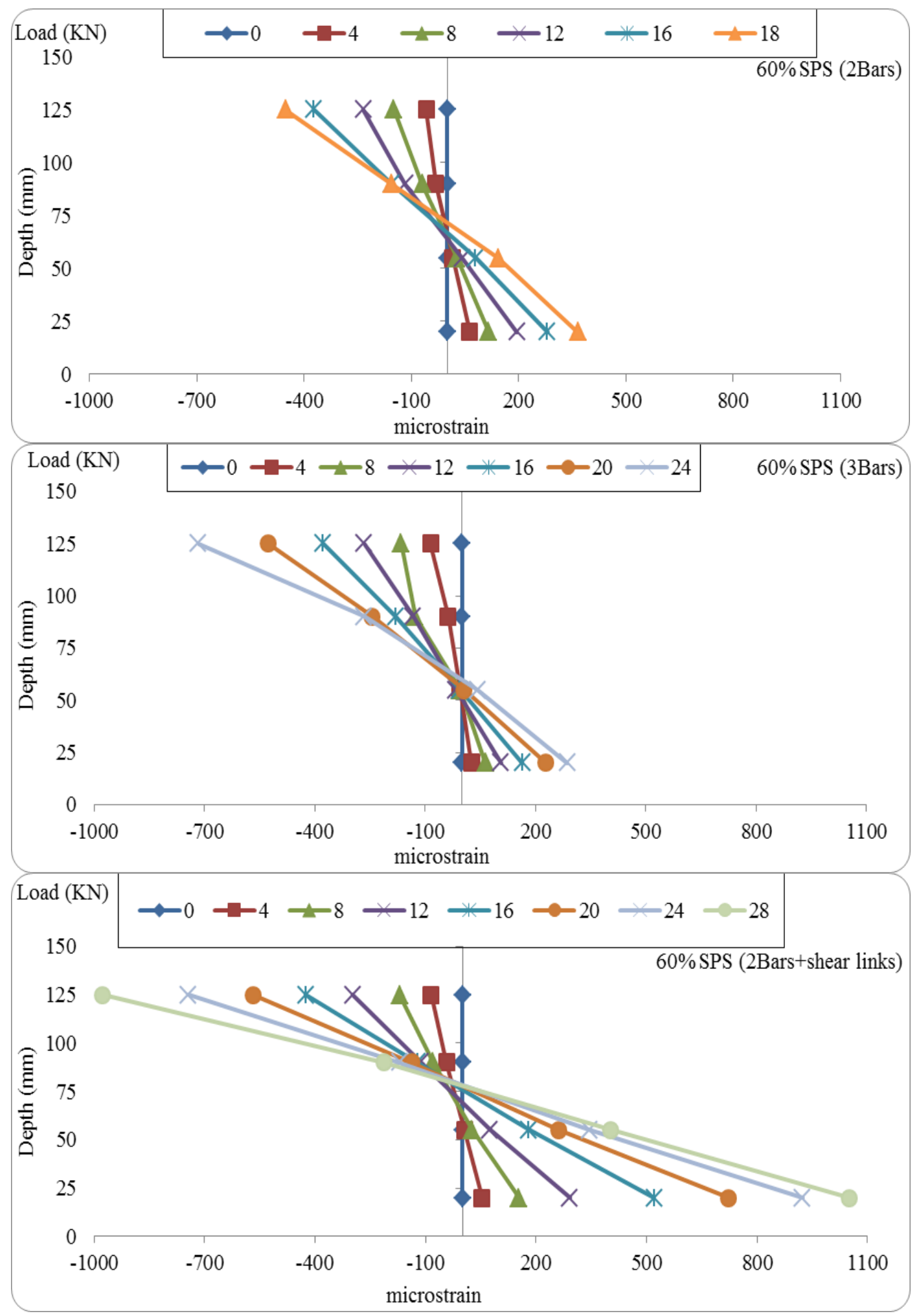

Fig. 26: Strain distribution of beams containing 60\% SPS aggregate with different reinforcements 


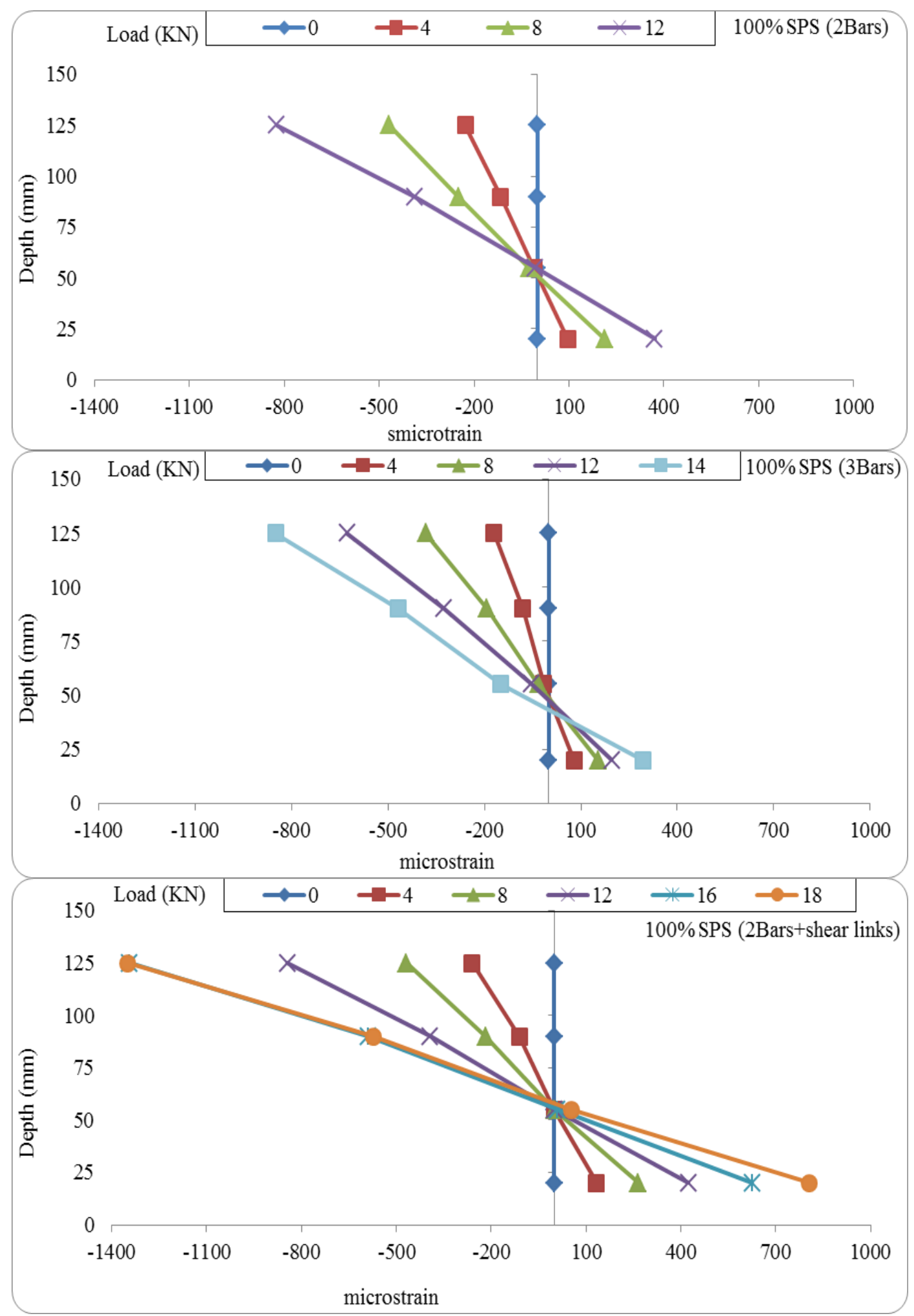

Fig. 27: Strain distribution of beams containing 100\% SPS aggregate with different reinforcements 

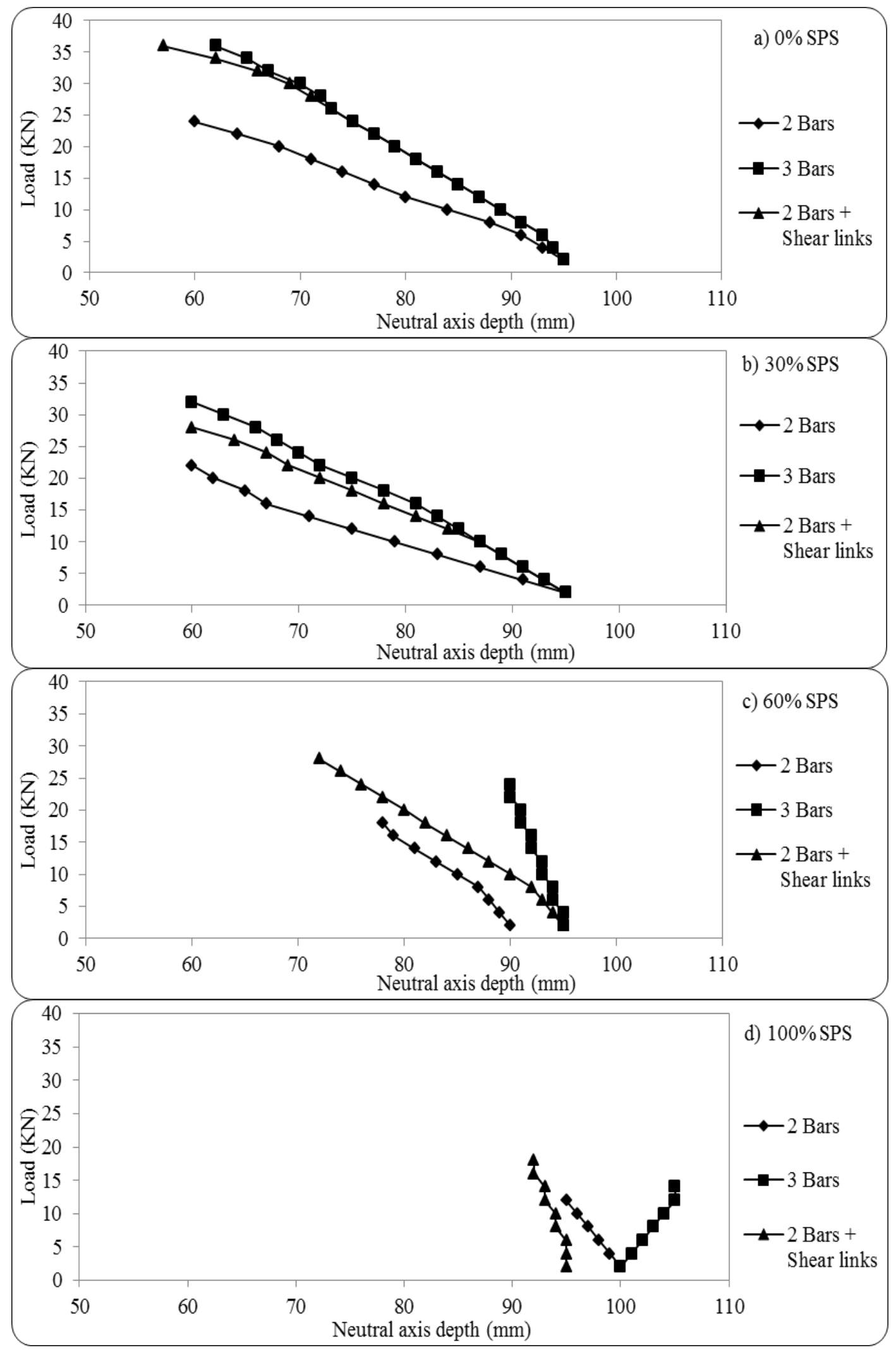

Fig. 28: Neutral axis depth of beams with different reinforcements for a) 0\% SPS, b) $30 \%$ SPS, c) $60 \%$ SPS and d) $100 \%$ SPS 


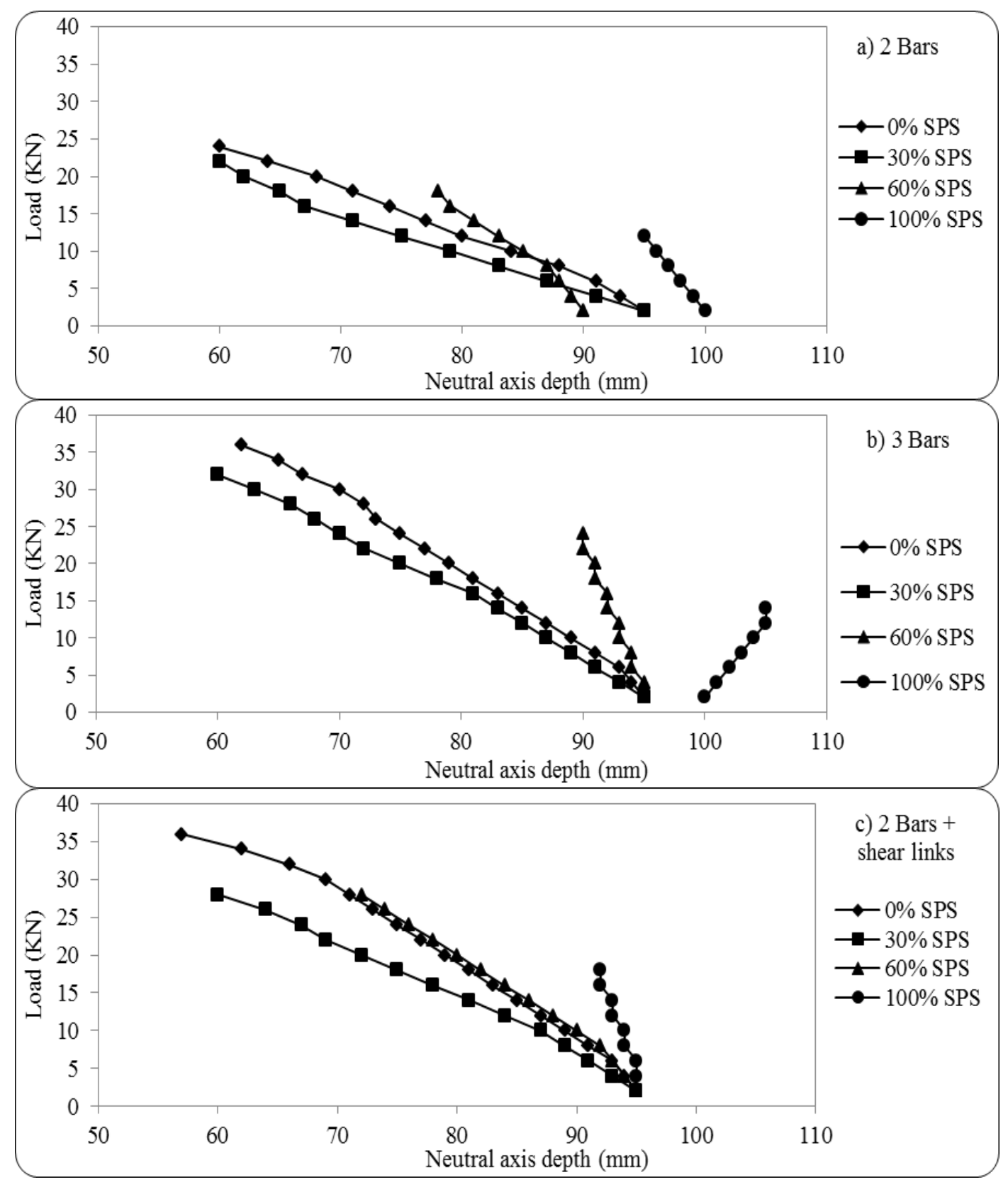

Fig. 29: Neutral axis depth of beams containing varying amounts of SPS aggregate for a) 2 bars, b) 3 bars and c) 2 bars + shear links reinforcements 